\title{
Er 'klart sprog' lettere at forstå? \\ En undersøgelse af forståelsen af to versioner af et brev fra SKAT
}

\author{
ANNE KJÆRGAARD \& TORBEN JUEL JENSEN
}

\begin{abstract}
I Danmark, såvel som i andre lande, har man i årtier forsøgt at gøre tekster fra offentlige myndigheder til almindelige borgere lettere at forstå for modtageren. Der mangler imidlertid empirisk belæg for at dette arbejde faktisk virker efter hensigten. I artiklen præsenteres en kvantitativ, eksperimentel undersøgelse af hvor godt læsere forstår to forskellige versioner af det samme brev fra SKAT - en oprindelig version som sprogmedarbejdere fra SKAT mente, var vanskelig at forstå, og en version der var omskrevet med henblik på at gøre brevet lettere at forstå. Det undersøges om den omskrevne version er lettere at forstå end den oprindelige, og hvordan faktorer som respondenternes uddannelse, alder, køn og læsefærdigheder påvirker forståelsen af teksterne. Analysen viser at den omskrevne version gennemsnitligt set er lettere at forstå end den oprindelige, og at uddannelse, læsefærdigheder, førstesprog og alder har betydning for forståelsen. Svage læsere har en betydeligt bedre forståelse af den omskrevne version end af den oprindelige, mens det for de bedste læsere i bedste fald ingen forskel gør for forståelsen hvilken version de læser. Artiklen afsluttes med en diskussion af hvilke elementer i den omskrevne version der tilsyneladende gør den lettere at forstå end den oprindelige.
\end{abstract}

EMNEORD: sproglig rådgivning, tekstforståelse, læsning, tekster fra offentlige myndigheder, klarsprog

\section{INDLEDNING}

I Danmark er sproget i tekster fra offentlige myndigheder til borgere gennem flere årtier blevet diskuteret kritisk og søgt forbedret. Et helt centralt omdrejningspunkt i den forbindelse er en række skriveråd, fx 
"undgå lange udredninger før du kommer til sagen", "undgå lange sætninger", "undgå passiver", "undgå verbalsubstantiver", "undgå lange sammensatte ord" og "undgå abstrakte ord og rene fagudtryk" (eksemplerne er taget fra Jensen et al. (2014: 18); se også Wille (2001)). Det er vigtigt at understrege at sproglig rådgivning, der har til formål at gøre tekster fra offentlige myndigheder lettere at forstå og mere imødekommende, under ingen omstændigheder kan reduceres til en ensidig bestræbelse på at eliminere disse og lignende sproglige træk. Sproglig rådgivning bedrives af mange forskellige aktører, og der er formentlig stor forskel på hvor stor en rolle de klassiske skriveråd spiller i forskellige dele af branchen. Wismar (2010: 24-41) viser imidlertid at rådene om at undgå passiver og verbalsubstantiver stadig er almindelige $i$ sprogguider fra offentlige og private organisationer, og de traditionelle skriveråd har også spillet en rolle for de tekster vi beskæftiger os med her i artiklen.

I de nordiske lande kender man til tilsvarende bestræbelser for at gøre sproget i tekster fra offentlige myndigheder til "almindelige borgere" (dvs. borgere uden særlige forudsætninger for at forstå tekster fra offentlige myndigheder) lettere at forstå og mere imødekommende. Rapporterne fra de såkaldte klarsprogskonferencer der er blevet arrangeret af de nordiske sprognævn siden 1998, giver et et indblik i bestræbelserne i Norden det sidste årti: http://ojs.statsbiblioteket.dk/ index.php/ksn/issue/archive. Fænomenet er også velkendt i en række lande uden for Norden: Kimble (2012) redegør for en række forsøg på at promovere det såkaldte plain language i en række (primært engelsktalende) lande, Janssen og Netuelings (2001) giver et indblik i hollandske forhold, Gogolok (2005) behandler tyske forhold, Solomon (1996) skriver om australske forhold, og Steinberg (1991) giver indblik i bl.a. japanske og canadiske forhold.

Det er flere gange blevet påpeget at der mangler empirisk forskning der kan underbygge praksis. I 1994 skrev Masson og Waldron at "the plain language movement remains very much a gospel in need of a theology" (1994: 68), og de er langt fra de eneste der har efterlyst mere forskning, se fx Solomon (1996: 304), Jensen (1998: 159), Wille (2001: 269), Søndergaard (2010: 8), Höög et al. (2012: 29) og Kjærgaard (2013: 217). 
Formålet med denne artikel er at bidrage til den sparsomme forskning ved at undersøge om et konkret forsøg på at forbedre et brev fra en offentlig myndighed (et brev fra SKAT) faktisk resulterer i en tekst der er lettere at forstå. Formålet er derudover at undersøge hvordan forskellige karakteristika ved læserne, først og fremmest uddannelse, alder, køn og læsefærdigheder, hænger sammen med deres forståelse af hhv. den oprindelige og den reviderede brevversion.

\section{FORSKNING I EFFEKTEN AF AT OMSKRIVE TEKSTER FRA OFFENTLIGE MYNDIGHEDER OG PRIVATE FIR- MAER TIL "ALMINDELIGE BORGERE"}

I forhold til at arbejdet med at få offentlige institutioner til at skrive mere forståligt og mere imødekommende lader til at være en ganske udbredt praksis i en del lande, og at der i hvert fald i Danmark gennem de seneste årtier er brugt mange resurser på det, er det forbløffende hvor lidt der faktisk er forsket i området. Der findes dog nogle studier der beskæftiger sig med feltet. Der er imidlertid ikke gjort særligt mange forsøg på, som anbefalet af Schriver og Gordon, at "gather and synthesise research relevant to plain language" (2010: 33). Den eksisterende forskning fremstår ikke som en samlet forskningstradition, og man kan være i tvivl om hvor meget de enkelte forskere egentlig kender til hinandens arbejde. Uagtet at der eksisterer nogen forskning, virker efterlysningerne efter mere forskning i øvrigt ikke urimelige. Den sparsomme forskningsindsats karakteriserer i øvrigt ikke bare modtageraspektet, som vi fokuserer på her $\mathrm{i}$ artiklen, men også aspekter ved fx afsenderinstitutionen (også her er der dog lavet nogen forskning, se fx Kjærgaard 2010, Nord 2011, Schriver 2012, Pedersen 2014 og Bendegard 2015).

Vi tør ikke gisne om hvorfor der generelt er bedrevet relativt lidt forskning indenfor feltet; men at det forholder sig sådan i Danmark, er formentlig en konsekvens af det metodiske og teoretiske fokus der var fremherskende i 70'erne da Erik Hansen udgav Ping- og Pampersprog, og bestræbelsen efter 'klart' og 'demokratisk' sprog for alvor begyndte at vinde gehør på danskfaget. Som Kjøller påpeger, havde bestræbelsen oprindeligt "fødderne solidt plantet i sætningsanalysen" (2016: 64). 
Fokus var på syntaks og i det hele taget på sprogligt-stilistiske iagttagelser i tekster foretaget af tekstanalytikere uddannet på universitetet. De konstruktioner der blev udpeget som problematiske (fx fordi de er påstået svære at forstå eller upersonlige), blev udpeget med udgangspunkt $i$ tekstanalytikernes vurderinger. Det betyder naturligvis ikke at den slags vurderinger nødvendigvis er forkerte; det er bare heller ikke sikkert at de er rigtige. Som påpeget af Kjøller var (og er) kritikken "båret af en demokratisk holdning som tager den almindelige borgers krav om forståelighed og lighed mest muligt på ordet” (2016: 60). Set i bakspejlet virker det næsten lidt ironisk at man, trods sin iver efter at tilgodese den almindelige borger, ikke gjorde sig den ulejlighed systematisk at inddrage borgeres reaktioner på de tekster man kritiserede. Hvis man ser på udviklingen indenfor den sproglige rådgivning som påvirket af de bredere tendenser indenfor forskningen i dansk sprog, er det imidlertid ikke så underligt at der de seneste år er nogen der er begyndt at interessere sig for kvantitative analyser af tekstreceptionen, se Balling (2013), Ingemansson og Jensen (2015) og Kjærgaard (2014, 2015a og under udgivelse). Kvantitative og eksperimentelle tilgange er blevet langt mere almindelige, og det betyder at man nu er i stand til at teste hvilken effekt forskellige tekstversioner har for læsere.

Også internationalt findes der studier af hvad det betyder for læseres forståelse at man reviderer informerende tekster fra offentlige myndigheder og private firmaer (fx lovtekster, formularer fra det offentlige, indlægssedler i medicin og kontrakter). Det gælder fx for Davis (1977), Walmsly et al. (1981), Gunnarsson (1982), Swaney et al. (1991), Masson og Waldron (1994), Campbell (1999), Dickinson et al. (2001), Jansen og Steehouder (2001), Pedersen (2004), Jones et al. (2012) og Demarmels et al. (2013). ${ }^{1}$

1 Her i artiklen fokuserer vi på undersøgelser af hvilken forskel forskellige tekstversioner gør for læsere. Det er ikke formålet at give en samlet fremstilling af al relevant forskning, men vi vil dog nævne at der også er andre tilgange til forsøget på at underbygge praksis empirisk. Wengelin (2015) tager udgangspunkt i en række af de skriveråd der florerer for svensk, og undersøger hvordan disse skriveråd underbygges af forskning i læsbarhed, sprogforståelse og sprogprocessering (se også Jansen (2001) (om hollandsk) for en lignende tilgang). Wengelin koncentrerer sig om en række råd på ord- og sætningsniveau og finder nogen støtte for især to af rådene (nemlig rådet om at bruge ord der er velkendte for læseren, og om at undgå "att skapa alltför koplexa meninger gennem bisatsindskott" (2015: 2)). Derudover konkluderer hun at meget af den forskning som de undersøgte råd bygger på, er baseret på engelsk, at 
Hvad angår forståelsesforskelle mellem oprindelige og omskrevne tekster, peger resultaterne ikke entydigt i samme retning: Det lader til at revisioner der begrænser sig til bestemte sproglige konstruktioner, $\mathrm{fx}$ passiver (Ingemansson og Jensen 2015), nominaliseringer, lange komplekse sætninger og ord mv. (se Balling 2013: 3 for en komplet liste over de konstruktioner hun beskæftiger sig med) eller brugen af pronomener og formuleringen af overskrifter som spørgsmål (Jones et al. 2012), ikke har nogen større betydning for tekstforståelse - om nogen overhovedet. Det gælder også i Campbell (1999), der på den ene side viser at tekster skrevet på "plain English" forbedrer forståelsen, men som på den anden side konkluderer at "linguistic and superficial design changes may not be enough to make the documents truly comprehensible" (1999: 354). Der er manipuleret ved flere af de ovennævnte træk i omskrivningen fra den ene til den anden af de to brevversioner vi undersøger (se afsnittet Materialer i metodeafsnittet): De fleksiviske passiver (s-passiverne) er fjernet, nominaliseringer er gjort til sætninger, den gennemsnitlige sætningslængde er kortere, og morfologisk komplekse og/eller sjældne ord er fjernet i den reviderede version. Disse faktorer undersøges imidlertid ikke enkeltvis i denne undersøgelse, tværtimod er der ændret ved alle disse faktorer i den reviderede brevversion.

Revisioner der udover bestemte sproglige konstruktioner også omfatter mere globale teksttræk ( $\mathrm{fx}$ informationsudvælgelse og -strukturering), lader derimod til at have større effekt på forståelse, jf. Dickinson et al. (2001), Jansen og Steehouder (2001), Swaney et al. (1991), Gunnarsson (1982) og Davis (1977). Den reviderede brevversion vi undersøger her $\mathrm{i}$ artiklen, minder mere om sådanne revisioner hvor der - ud over at være ændret i ovennævnte rent sproglige faktorer - også er foretaget ændringer $\mathrm{i}$ både informationsudvælgelse og -strukturering (se afsnittet Materialer).

I denne undersøgelse ønsker vi også at se på om effekten af revisionen er afhængig af en række forskellige læservariable, nemlig uddan-

nyere forskning der kaster nyt lys over resultaterne af den tidligere forskning, ikke har ført til at rådene er blevet omformuleret, og at resultater fra undersøgelser af afgrænsede ord og sætninger bliver generaliseret til tekstforståelse i kontekst - en generalisering der ikke nødvendigvis er uproblematisk. Fremtidige forsøg på empirisk at underbygge de skriveråd der florerer i dansk kontekst, kunne på lignende vis inddrage forskning i læsbarhed, sprogforståelse og sprogprocessering for dansk. 
nelse, alder, køn, læsefærdigheder og førstesprog. Af de læservariable vi undersøger $\mathrm{i}$ artiklen, er uddannelse tilsyneladende den mest velundersøgte, og sammenhængen mellem uddannelse og forståelse af informerende tekster fra offentlige myndigheder og private firmaer synes at være rimeligt entydig: Personer med lang uddannelse har generelt en bedre tekstforståelse end personer med kort uddannelse (Ingemansson og Jensen 2015: 140; Gunnarsson 1982: 253; Jones et al. 2012: 341). Det påpeges dog i en kvalitativ interviewundersøgelse fra Penge- og Pensionspanelet (2010) om forståelse af realkreditinstitutters skriftlige materiale at respondenternes uddannelsesniveau "kun [har] nogen indflydelse på den generelle forståelse af materialet. Det er i højere grad interesse og flair for/erfaring med økonomi og økonomistyring generelt, som har indflydelse på tilgangen til og forstålsen af materialet" (2010: 7).

Sammenhængen mellem alder og forståelse behandles i Davis (1977) der når frem til at unge forstod den oprindelige tekst (en afdragsaftale) dårligst. I Davis' undersøgelse stiger forståelsen i takt med alderen, $i$ hvert fald op til gruppen af respondenter der er 45 år og derover (jf. s. 870). Davis konkluderer i øvrigt at unge respondenter var en af de grupper der havde mest glæde af en omskrevet og simplificeret afdragsaftale (1977: 872). Penge- og Pensionspanelet skriver i deres undersøgelse at "[s]ærligt de yngre og mindre erfarne låntagere" i højere grad benytter sig af deres bankrådgiver, mens "[f]lere ældre og mere erfarne låntagere føler, at de besidder en baggrundsviden, som til dels overflødiggør rådgiverens rolle” (2010: 5). Hvis de ældre respondenters fornemmelse står mål med deres faktiske formån, kunne det tyde på at ældre låntagere er bedre til at forstå materialet end yngre. Gunnarsson finder imidlertid en modsat sammenhæng mellem alder og forståelse (af lovtekst), nemlig at lav alder hænger sammen med høj forståelse (1982: 251-252). Gunnarsson når derudover frem til at lang erhvervserfaring og kort uddannelse også påvirker forståelsen negativt, og påpeger at der er en sammenhæng mellem høj alder, lang erhvervserfaring og kort uddannelse; det antydes således at den negative sammenhæng mellem alder og forståelse kan skyldes at Gunnarssons ældre respondenter har en kortere uddannelse (1982: 261). 
Hvad angår sammenhængen mellem køn og forståelse, finder Gunnarsson at der i de fleste af hendes respondentgrupper ikke er nogen statistisk signifikant sammenhæng mellem køn og det samlede antal point i forståelsestesten (1982: 250), og hun konkluderer at kønsvariablen giver et ganske lille bidrag som forklaring på tekstforståelse (Gunnarson 1982: 250). I den kvalitative analyse fra Penge- og Pensionspanelet er "det typiske billede [blandt parrene i undersøgelsen], at den mest økonomisk bevidste gennemlæser papirerne (her ses en overvægt af mandlige respondenter) og evt. gennemgår den med partneren" (2010: 6). Der er derudover noget der tyder på at der er forskel på hvilke økonomiske områder kønnene hver især tager sig af. I en artikel fra Bolius (Boligejernes Videncenter, 2013) kan man læse at det i familier typisk er kvinder der står for køb af tøj, dagligvarer, gaver og boligindretning, mens mænd står for elektronik, boliglån, forsikringer og kontrakter på $\mathrm{el}$, vand og varme. Undersøgelsen her i artiklen handler som allerede nævnt om et brev fra SKAT, og det kunne tyde på at skat er et område som mænd typisk tager ansvar for - og dermed et område som de har mere erfaring med og dermed bedre forudsætninger for at forstå.

Vi kender kun til et enkelt studie der undersøger sammenhængen mellem forstålse af forskellige versioner af informerende borgerrettede tekster og læsefærdigheder, nemlig Walmsley et al. (1981). I artiklen undersøger de bl.a. om forsøg på at simplificere tekster til ældre påvirkede gode og svage læsere forskelligt. Undersøgelsen viste at uanset om en tekst var forsøgt simplificeret eller ej, så forstod de gode læsere teksterne bedst. De svage læseres forstålse blev i øvrigt ikke nævneværdigt bedre når de læste reviderede versioner (1981: 242).

Der er derudover lavet en række studier af læsefærdigheder i forskellige lande, se fx Elbro et al. (1995) om Danmark. Elbro et al. finder bl.a. at personer med lav uddannelse har ringere læsefærdigheder end personer med lang uddannelse, og at personer over 45 har ringere læsefærdigheder end yngre (1995: 265). Elbro et al. finder ikke signifikante forskelle mellem læsevanskeligheder blandt kvinder og mænd (1995: 265). Disse resultater minder således om de resultater man er nået frem til i flere undersøgelser af forståelsen af informerende tekster fra offentlige myndigheder og private firmaer (se ovenfor). Det kan meget vel være at sådanne mere generelle karakteristika ved forskellige gruppers 
læsefærdigheder har indflydelse på resultaterne af forståelsesundersøgelserne. Det er dog vigtigt at understrege at de to typer undersøgelser ikke handler om det samme: Elbro et al. tager udgangspunkt i flere forskellige tekster (en avisartikel, to informative tekster (om skat og en brandinstruks), et bykort og et skema fra posthuset) og er på grundlag af dette ganske alsidige tekstudvalg interesseret $\mathrm{i}$ at afdække generelle læsefærdigheder. Vi er derimod snævert interesserede i forståelsen af en særlig tekstgenre, nemlig breve fra det offentlige, og mens Elbro et al. valgte "the most easily comprehensible piece of information available about this aspect of tax legislation" (1995: 262), kan det meget vel være at brevet der indgik i vores undersøgelse, stillede større krav til respondenterns forudsatte baggrundsviden (se afsnittet Metode).

Sprogkundskabers betydning lader ikke til at være blevet undersøgt i relation til forsøget på at gøre tekster fra det offentlige og private lettere at forstå. Bartell et al. (2006) konkluderer at der er signifikante forskelle på forståelse af papir- og onlinetekster mellem "native English versus nonnative English speakers" (2006: 420, fremhævelse fra originalen) - de to kategorier defineres dog ikke mere præcist. Forskellen består $i$ at gruppen af "native" engelsktalende har en bedre tekstforståelse end gruppen af "nonnative" engelsktalende. Det er dog vigtigt at understrege at undersøgelsens fokus (forskelle i forståelsen af papir- og onlinetekster) ikke er det samme som her i undersøgelsen. Det bør i øvrigt bemærkes at det ikke kan konkluderes at en forskel i tekstforståelse mellem grupper af respondenter der adskiller sig mht. om de har tekstens sprog som første- eller andetsprog, relaterer sig til sprogkundskaber i snæver forstand. Forskellen kan også relatere sig til forskelle i den gennemsnitlige, kulturelt eller socioøkonomisk relaterede baggrundsviden mellem grupperne.

\section{HYPOTESER}

På grundlag af ovenstående gennemgang har vi opstillet følgende hypoteser:

1. Omskrivningen, der trækker på en række af de råd man traditionelt arbejder ud fra i den sproglige rådgivning, har betydning for forstå- 
elsen. Dvs. den omskrevne version (V2) er lettere at forstå end den oprindelige version (V1).

2. En række læserkarakteristika har betydning for forståelsesniveauet: uddannelsesniveau, alder, køn, modersmål og generelle læsefærdigheder.

3. Der er interaktionseffekt mellem omskrivningen og læserkarakteristika. Dvs. omskrivningen har større betydning for svage "forståere" (som ud fra den sparsomme eksisterende forskning må formodes at være lavtuddannede, yngre, kvinder, personer med dansk som L2 og svage læsere) end for gode "forståere".

\section{METODE}

\section{To versioner af et brev fra SKAT}

Den første brevversion (V1) er et eksempel på en tekst som de relevante sprogmedarbejdere ${ }^{2}$ hos SKAT ikke var tilfredse med, og som de derfor reviderede. Den anden brevversion (V2) er et resultat af revisionsarbejdet: Sprogmedarbejderne lavede et udkast der blev godkendt af en inddrivelsesmedarbejder (altså en person med indsigt i det fagområde som brevet handler om). Derefter blev brevet sendt ud til 200 borgere der skulle have foretaget lønindeholdelse, og nogle af disse modtagere medvirkede i en brugerundersøgelse om brevet. På grundlag af brugerundersøgelsen tilpassede sprogmedarbejderne yderligere brevet, og det resulterede i V2 der fik Erhvervssprogprisen i 2011.

Oprindeligt indgik der tre forskellige brevversioner i undersøgelsen. ${ }^{3}$ I denne artikel beskæftiger vi os kun med to brevversioner, V1 og V2, fordi disse to versioner af brevteksten adskiller sig mest fra hinanden. V1 og V2 er gengivet som bilag 1 og 2. Begge brevversioner var vedlagt et budgetskema, se bilag 3 .

I brevet får modtageren at vide at vedkommende har en gæld til det offentlige som SKAT vil inddrive ved at trække i modtagerens løn. Her

2 Sprogmedarbejderne var tilknyttet projektet Godt sprog i SKAT, der bl.a. har til opgave at omskrive en lang række breve, e-mails og nettekster for at gøre dem mere forstålige og imødekommende.

3 Studiet blev finansieret af Kulturministeriet og Dansk Sprognævn. SKAT bidrog ikke til finansieringen. 
følger en kort - og ikke udtømmende - karakteristik af forskellene mellem de to brevversioner (se i øvrigt også Kjærgaard 2015b).

De mest iøjnefaldende forskelle mellem de to versioner vedrører håndteringen af nogle af de temmelig vanskelige ord der optræder i V1, dvs. ord der må formodes at være sjældent forekommende eller morfologisk komplekse. Fx bruges ordet lonindeholdelse (altså et ord der er knyttet til det særlige skattemæssige fagområde brevet handler om) 27 gange i V1. Ordet forekommer bl.a. i brevets hovedoverskrift, "Varsel om lønindeholdelse til dækning af parkeringsafgift m.fl.". Betydningen af ordet forklares ikke. I den reviderede version (V2) forekommer ordet ikke, i stedet parafraseres det, $\mathrm{fx}$ i hovedoverskriften der lyder "SKAT vil trække i din løn som betaling på din gæld". På lignende vis er "indkomstforhold" blevet til "indkomst", og "returnere" er blevet til "sende" i V2. Den temmelig lange sammensætning "lønindeholdelsesprocenten" er blevet opløst til et substantivsyntagme med en relativsætning ("den procent, vi trækker i din løn"), og "forhøjelse" er blevet parafraseret til en aktiv betingelsesledsætning ("hvis vi vil forhøje procenten") i V2.

Et af de træk der har modtaget en ganske betydelig opmærksomhed i arbejdet med at gøre tekster fra det offentlige lettere at forstå (se fx Ingemansson og Jensen (2015)), er fleksiviske passiver. I V1 er der 8 fleksiviske passiver, i V2 er der ikke nogen forekomster, dvs. der er helt i overensstemmelse med de klassiske råd - skåret ned på antallet.

Den gennemsnitlige sætningslængde i V1 er på 19,9 ord, mens den i V2 er faldet til 16,4. Det dækker især over at henvisninger til love er behandlet anderledes. For det første er de placeret i selvstændige sætninger i V2, for det andet er de væsentligt kortere end i de tilsvarende henvisninger i V1 ( $\mathrm{fx}$ er henvisningen "kapitel 5 i bekendtgørelse nr. 1365 af 19.12.2008 om inddrivelse af gæld til det offentlige (inddrivelsesbekendtgørelsen) jf. \ $10 \mathrm{i}$ lov nr. 1333 af 19.12.2008 om inddrivelse af gæld til det offentlige (inddrivelsesloven)" i V1 blevet til "inddrivelsesbekendtgørelsens kapitel 5 og i inddrivelseslovens \10" i V2).

V1 er på 624 ord, mens V2 er på 497 ord. Forskellen i længde skyldes især at en række informationer er udeladt i V2, fx informationer der indgår i henvisninger til love (se ovenfor). Også andre informationer er udeladt: I V1 kan man fx læse at "Lønindeholdelsen vil blive tilbage- 
kaldt, når restancen er indfriet”. I V2 får læseren ikke nogen tilsvarende information om hvor længe SKAT vil trække penge fra modtagerens indkomst.

De to breve adskiller sig også hvad angår informationsstrukturering. I V1 er al information formidlet som løbende tekst, mens der i V2 er et skema først i brevet der viser hvor modtagerens gæld stammer fra, og hvor stor den samlede gæld er. Overskrifterne bruges også forskelligt $\mathrm{i}$ de to versioner. I V1 angiver de et tema, fx "Lønindeholdelsesprocent" eller "Budgetskema". I V2 lyder de tilsvarende overskrifter "Vi vil trække en procentdel af din løn" og "Du kan sende et budgetskema inden 15 dage". Overskrifterne indeholder således flere informationer, især om hvem der skal gøre hvad.

\section{Forståelsessporgsmål}

Respondenternes forståelse blev undersøgt ved at lade dem besvare en række spørgsmål om den brevversion de havde fået udleveret. De forskellige brevversioner og spørgsmål stiller forskellige krav til læseren. Nogle svar står direkte i teksten, andre svar bliver læseren nødt til at slutte sig til.

De forståelsesspørgsmål der indgår her i artiklen (F1-F8), var de spørgsmål fra spørgeskemaet der opfyldte følgende tre kriterier:

1. SKAT har til hensigt at modtageren skal kunne besvare spørgsmålet på grundlag af teksten og på grundlag af relevant baggrundsviden. Om spørgsmålene opfyldte dette kriterium, blev afgjort på grundlag af brevene og på grundlag af diskussioner med en kontaktperson hos SKAT. Inddragelsen af baggrundsviden skal bl.a. tydeliggøre at ingen af spørgsmålene kunne besvares uden en eller anden form for baggrundsviden, blandt andet en basal forståelse af det danske skattesystem.

2. Svarene skulle kunne kategoriseres som enten rigtige eller forkerte (så der kunne skelnes mellem 'forstået' og 'ikke-forstået').

3. Svarene skulle grundlæggende være de samme i de to versioner (eftersom formålet var at sammenligne forskellige måder at formidle den samme information på). 
F1, F4, F5, F6 og F7 var multiple choice-spørgsmål med fem svarmuligheder hvoraf en var korrekt. Respondenterne kunne sætte kryds i en svarmulighed med teksten Ved ikkelandet (skriv gerne hvad), og ud for denne svarmulighed var der en linje hvor de kunne skrive et alternativt svar. Anne Kjærgaard vurderede om svaret var rigtigt eller forkert. Hvis der ikke var skrevet noget alternativt svar, blev svarene regnet som forkerte.

F2, F3 og F8 var åbne spørgsmål. Svarene på de tre spørgsmål kunne kopieres fra brevteksten og stillede dermed ikke høje krav til respondenternes formuleringsevner.

De otte spørgsmål (F1-F8) og de tilhørende svarmuligheder er gengivet i bilag 4. I bilag 5 kan man læse efter hvilke kriterier svarene på de tre åbne spørgsmål (F2, F3 og F8) blev kategoriseret som hhv. rigtige og forkerte.

For alle spørgsmål gælder det at manglende besvarelse eller besvarelsen "Ved ikke" i den efterfølgende analyse bliver regnet som et forkert svar.

\section{Test af lasefardighed}

Respondenternes læsefærdighed blev testet vha. Lasetekster for unge og voksne (Arnbak 2001) (kun tekstgruppe 3). Testen er udviklet til at måle funktionel læseforståelse hos unge og voksne, altså "den enkeltes læsefærdighed i forhold til de læsekrav, han eller hun er stillet overfor i hverdagen” (Arnbak 2001: 6). Tekstgruppe 3 i undersøgelsen består af 6 forskellige avisartikler og 20 multiple choice-spørgsmål til artiklerne. Denne del af læsetesten blev udvalgt fordi der tidligere er påvist høj korrelation mellem resultaterne i denne del af testen og handelsskoleelevers samlede læseforståelsesscore (jf. Petersen (2008: 15) der på det grundlag også kun bruger denne tekstgruppe). 


\section{Deltagere}

Kriteriet for at rekruttere respondenter var at de skulle være individer som kunne have modtaget brevet. Dette kriterium opfyldes af alle der kunne skylde penge til den danske stat, et kriterium der i princippet er opfyldt af alle voksne mennesker der bor i Danmark. Ideelt set skulle undersøgelsen altså tage udgangspunkt $i$ et repræsentativt udvalg af den danske befolkning, men det var ikke muligt indenfor de tidslige og økonomiske rammer. I stedet blev deltagerne i undersøgelsen rekrutteret fra uddannelsesinstitutioner. For at sikre en vis diversitet blev deltagerne rekrutteret blandt lærerstuderende, gymnasie- og HF-elever, AVU-kursister ${ }^{4}$ og folk der læste til SOSU-hjælper. Respondenterne var 17-59 år gamle.

De $i$ alt 453 respondenter der indgår i undersøgelsen, fordeler sig således $\mathrm{i}$ forhold til køn, alder og uddannelsesniveau:

TABEL 1: UNDERSØGELSENS RESPONDENTER

\begin{tabular}{|l|l|l|l|}
\hline & Seminarium & $\begin{array}{l}\text { Gymnasium } \\
\text { (inklusive HF) }\end{array}$ & $\begin{array}{l}\text { Andet (SOSU-hjælper/ } \\
\text { AVU) }\end{array}$ \\
\hline Antal (kvinder+mænd) & $176(119+57)$ & $188(110+78)$ & $89(60+29)$ \\
\hline Gennemsnitsalder & $24,75(19-50)$ & $22,62(17-45)$ & $27,81(17-59)$ \\
\hline
\end{tabular}

\section{Fremgangsmåde}

Respondenterne fik udleveret et samlet spørgeskema som de fik i alt en time til at udfylde. Alle respondenter blev præsenteret for det samme spørgeskema og en af de to brevversioner. Spørgeskemaet blev udfyldt i undervisningstiden. Respondenterne fik først 15 minutter til at lave læsetesten og måtte ikke gå videre til forståelsesspørgsmålene selvom de blev færdige for tiden var gået. Herefter fik de 45 minutter til at læse brevet fra SKAT og besvare resten af spørgeskemaet. Da der ikke var tale om en hukommelsestest, måtte respondenterne gerne bladre tilbage i spørgeskemaet og kigge i brevet når de besvarede spørgsmålene i spørgeskemaet. Spørgeskemaerne blev udfyldt på papir og efterfølgende tastet ind i programmet SurveyXact.

4 AVU (almen voksenuddannelse) er enkeltfagsundervisning for voksne. Fagene kan afsluttes med prøver der svarer til folkeskolens afsluttende prøver. 
Alle spørgeskemaer blev udfyldt ved at Anne Kjærgaard kom på besøg hos de medvirkende klasser, præsenterede sig som en forsker fra Dansk Sprognævn der undersøgte hvor let det er for almindelige borgere at forstå breve fra det offentlige, og uddelte spørgeskemaerne. Begge brevversioner blev uddelt i alle klasser, dvs. en tredjedel af hver klasse fik V1 og en tredjedel V2 ${ }^{5}$. Anne Kjærgaard forblev i lokalet under hele undersøgelsen.

Der blev indsamlet $\mathrm{i}$ alt 467 spørgeskemaer om V1 og V2 ${ }^{6}$. I resultatbehandlingen blev i alt 14 respondenter dog frasorteret fordi de ikke havde besvaret spørgsmålene vedrørende køn, førstesprog eller alder (og ofte heller ikke mange af de øvrige spørgsmål).

Den afhængige variabel i undersøgelsen var respondenternes forståelse af de to brevversioner, dvs. besvarelserne af de otte forståelsesspørgsmål. Disse blev analyseret dels hver for sig, dels i form af et samlet forståelsesindeks (FIndeks) som udgøres af andelen af rigtige svar af de otte spørgsmål for hver enkelt respondent. De uafhængige variable var ud over brevversionen (Brevversion; V1 vs. V2) respondentens score i læsetesten (LScore; 0-20), køn, alder og uddannelse samt hvilket sprog respondenten selv har angivet at være bedst til (dansk/dansk+/andet) ${ }^{7}$.

For at undersøge om omskrivningen betyder mere for de svage "forståere" (jf. hypotese 3) testede vi for en eventuel interaktion mellem variablen brevversion og de øvrige uafhængige variable.

\section{RESULTATER}

Samlet forståelse af de to breve (forståelsesindeks)

Figur 1 nedenfor viser en oversigt over sammenhængene mellem forståelsen af meddelelsen fra SKAT og undersøgelsens uafhængige variable.

5 Den sidste tredjedel fik V3, der som nævnt ikke inddrages her i artiklen.

6 I alt blev der indsamlet 714 spørgeskemaer, men spørgeskemaer om V3 inddrages ikke i denne artikel. Kjærgaard (2015a) opgør i øvrigt det samlede antal spørgeskemaer til 717. Det har dog siden vist sig at tre spørgeskemaer var ukomplette dubletter af andre spørgeskemaer (genereret $\mathrm{i}$ forbindelse med indtastningen af skemaerne).

7 "Dansk+" angiver at respondenten har angivet at vedkommende er lige god til dansk og et andet sprog. 


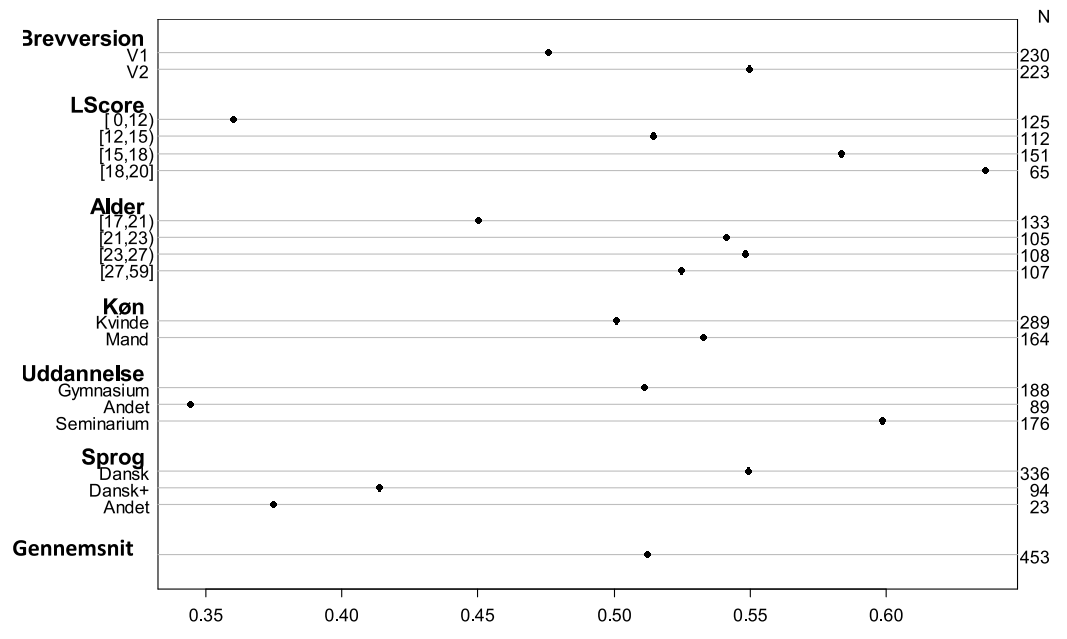

Forstålsesindekset (andel korrekte besvarelser af de otte forstälsessporgsmäl) set i forbold til undersogelsens nafhangige variable.

Umiddelbart bekræfter resultaterne hovedparten af vores hypoteser: V2 har et højere forståelsesindeks (dvs. er lettere at forstå) end V1, og hermed bekræftes hypotesen om at den omskrevne version er lettere at forstå end den oprindelige version. Også hypotesen om at læserkarakteristika har betydning for forståelsesniveauet, bekræftes. I overensstemmelse med hvad man kunne forvente fra tidligere undersøgelser, scorer gode læsere således (væsentligt) højere end svage læsere, mænd scorer højere end kvinder, seminariestuderende højere end gymnasie-/ HF-studerende, som igen scorer højere end SOSU-/AVU-studerende, og respondenter der har dansk som førstesprog, scorer højere end personer der angiver at være lige gode til dansk og et andet sprog, eller som er bedre til et andet sprog end dansk (de to sidstnævnte grupper ligger tæt på hinanden, og da gruppen der angiver at være bedst til et andet sprog end dansk, samtidig er meget lille, bliver de i de følgende analyser slået sammen til en). Der ser dog kun ud til at være en positiv effekt af stigende alder indtil en vis alder hvorefter effekten af alder er negativ (aldersgruppen 27-59 år har et lavere gennemsnitligt forståelsesindeks end de 23-27-årige). Det sidste svarer i øvrigt til hvad Elbro 
et al. tidligere har fundet $\mathrm{i}$ undersøgelser af generelle læsefærdigheder (1995: 257).

Ovenstående billede skal dog kun ses som indledende resultater idet det på flere måder kan være misvisende. For det første kan den tilsyneladende effekt af en variabel i virkeligheden være afledt af en anden, fx kunne effekten af uddannelse alene skyldes at seminariestuderende er bedre læsere end de øvrige grupper, eller at der er en større andel af personer med dansk som andetsprog hos de SOSU-/AVU-studerende end hos de øvrige grupper, og effekten af alder kunne skyldes de lidt forskellige aldersfordelinger på de forskellige uddannelser (jf. Tabel 1). Selvom brevversionerne blev fordelt tilfældigt mellem respondenterne $i$ hver enkelt klasse, er der naturligvis også en risiko for at de to grupper gennemsnitligt set ikke er lige gode læsere. For det andet kan de uafhængige variable interagere med hinanden, og som tidligere nævnt er vi her specielt interesserede $i$ at undersøge om effekten af brevversionen interagerer med nogle af de øvrige variable, dvs. om betydningen af omskrivningen eksempelvis er større for kvinder end for mænd (jf. vores hypotese om at omskrivningen har større betydning for svage "forståere").

Vi analyserede derfor resultaterne vha. multipel lineær regression, dvs. en analyse som søger at bestemme sammenhængen mellem en afhængig variabel (i dette tilfælde forståelsesindekset) og flere uafhængige (dvs. potentielt forklarende) variable samtidig. For alle variable testede vi om der var en signifikant interaktion med Brevversion. Tabel 2 viser den model der bedst beskriver variationen i data mht. forståelsesindekset, dvs. den indeholder kun de variable og interaktioner som statistisk signifikant forbedrer modellens evne til at forudsige respondenternes forståelsesindeks. 
TABEL 2: BEDSTE MODEL FOR FORSTÅELSESINDEKS (FINDEKS)

\begin{tabular}{|l|l|l|l|}
\hline Prædiktor & Estimat & Standardfejl & Signifikansniveau \\
\hline (Skæringspunkt) & $-0,2114555$ & 0,1154304 & 0,06764 \\
\hline Brevversion:V2 & 0,2026958 & 0,0613917 & $0,00104 * *$ \\
\hline LScore & 0,0244683 & 0,0033915 & $2,35 \mathrm{e}-12 * * *$ \\
\hline Sprog:Andet & $-0,0512344$ & 0,0238118 & $0,03196 *$ \\
\hline Uddannelse:Andet & $-0,0804411$ & 0,0288977 & $0,00560 * *$ \\
\hline Uddannelse:Seminarium & 0,0287774 & 0,0212253 & 0,17585 \\
\hline Alder & 0,0223237 & 0,0072224 & $0,00212 * *$ \\
\hline Alder ${ }^{2}$ & $-0,0002684$ & 0,0001127 & $0,01768 *$ \\
\hline BrevversionV2*LScore & $-0,0090255$ & 0,0043659 & $0,03929 *$ \\
\hline $\begin{array}{l}\text { Observationer: } 453 \\
\mathrm{R}^{2:} 0,3235, \text { justeret } \mathrm{R}^{2}: 0,3113\end{array}$ & & \\
\hline
\end{tabular}

Analysen ${ }^{8}$ viser at variablene Brevversion, LScore (i læsetesten), Sprog, Uddannelse og Alder (men altså ikke Køn) har en statistisk signifikant indflydelse på den samlede forståelse af brevet. Der er desuden en signifikant interaktion mellem Brevversion og scoren i læsetesten (LScore), men ikke med de øvrige uafhængige faktorer.

Den mindste effekt ses i forbindelse med variablen Sprog, hvor respondenter med dansk som førstesprog som ventet har en bedre forståelse (af begge versioner af brevene) end de øvrige. ${ }^{9}$ Herefter kommer variablen Uddannelse, hvor såvel gymnasie- som seminariestuderende har en bedre forståelse af brevene end SOSU-/AVUstuderende, mens gymnasie- og seminariestuderende ikke adskiller sig signifikant fra hinanden.

Nogenlunde tilsvarende effektstørrelse ses i forbindelse med variablen Alder. Sammenhængen mellem Alder og FIndeks er imidlertid

8 Analysen blev udført i R (version 3.3.1) med funktionen $l m$ i pakken stats.

9 Analysen er foretaget ud fra såkaldt treatment coding hvilket vil sige at betydningen af hver værdi i forbindelse med kategoriske variable som Sprog (i modsætning til numeriske variable som LScore og Alder) sammenlignes med den valgte referenceværdi. For variablen Sprog er referenceværdien sat til "Dansk" fordi det er den hyppigst forekommende værdi (jf. figur 1). Estimatet i Tabel 2 ud for Sprog angiver således hvor meget forståelsesindekset ændrer sig når Sprog er "Andet" fremfor "Dansk". Værdien er negativ hvilket vil sige at respondenter der ikke har dansk som førstesprog, alt andet lige har et forståelsesindeks der er ca. 0,05 lavere end for respondenter med dansk som førstesprog. Af Tabel 2 ses det endvidere at forskellen mellem "Andet" og "Dansk" er signifikant idet p-værdien er 0,03196, dvs. mindre end 0,05. 
nonlinexr (modellen indeholder således variablen Alder i anden potens): Forståelsen stiger med alderen, men først og fremmest blandt de yngste respondenter. Effekten flader ud ved 35-40-årsalderen og ser ligefrem ud til at være negativ blandt den ældste del af informanterne, dvs. her falder forståelsen en smule med alderen. Mest interessant er naturligvis effekten af Brevversion, som vises i Figur 2 sammen med LScore idet de to variable som nævnt interagerer med hinanden. ${ }^{10}$ Det fremgår her at forståelsen for begge brevversioner som ventet stiger med læsescoren; mere interessant er det imidlertid at forskellen mellem de to brevversioner afhænger af respondentens læsescore: For de svageste læsere ses en klart større forståelse af version 2 end version 1 (dette ses ved at sammenligne den venstre del af graferne i de to vinduer), men effekten af omskrivningen falder med læsescoren, og for de bedste læsere er der således ingen forskel mellem version 1 og 2 (dette ses ved at sammenligne den højre del af graferne i de to vinduer).

FIGUR 2. PARTIELLE EFFEKTER AF BREVVERSION OG LSCORE

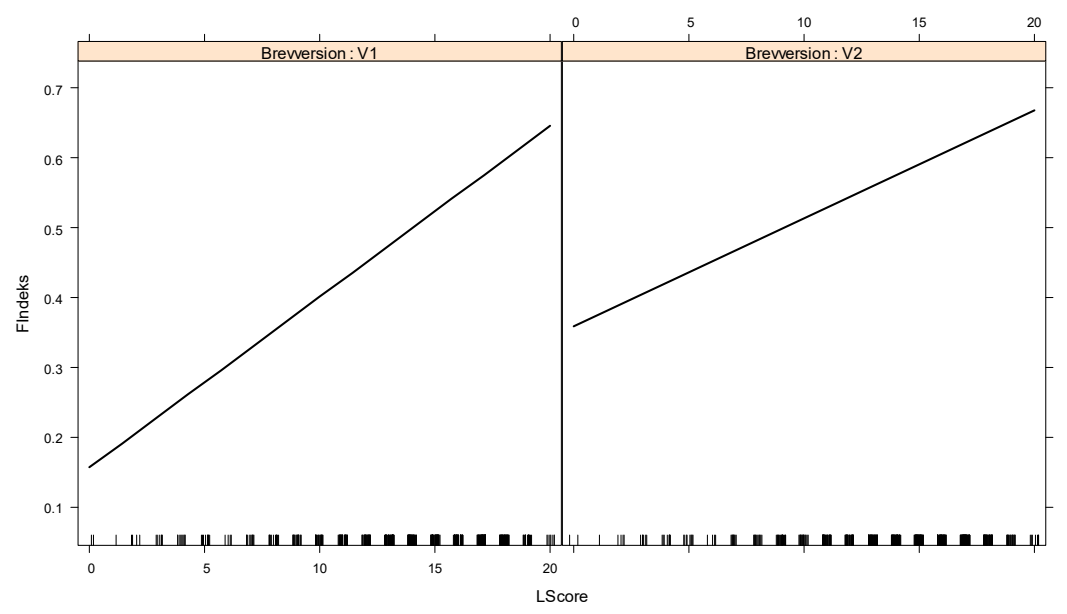

De angivne FIndeks-vardier er beregnet ud fra at de ovrige variable i modellen boldes på deres referencevardier, som er Sprog $=$ Dansk, Uddannelse $=$ Gymnasium og Alder $=24,47$ (gennemsnit).

10 Figuren er lavet i R (version 3.3.1) med pakken effects, version 3.1-1. 
Resultaterne af regressionsanalysen bekræfter således alle vores hypoteser bortset fra den om køn. Mht. alder er der den modifikation at den positive effekt af stigende alder tager af i 35-40-årsalderen, hvilket dog svarer til hvad man finder i undersøgelser af generelle læsefærdigheder. Desuden gælder det for variablen Brevversion at den positive effekt af omskrivningen først og fremmest ses hos de svage læsere. Herved bekræftes vores hypotese om at omskrivningen betyder mest for de svage "forståere", i forhold til denne variabel, men altså ikke i forhold til de øvrige.

\section{Hvilke andringer betyder noget for forstålsen?}

Hvis man ønsker at se nærmere på hvilke specifikke omskrivninger der har effekt på forståelsen, er det imidlertid nødvendigt at se på resultaterne i forbindelse med de enkelte spørgsmål hver for sig. Vi udførte derfor tilsvarende regressionsanalyser af delresultaterne for hvert enkelt spørgsmål - i form af logistisk regression idet den afhængige variabel i modsætning til forståelsesindekset her er kategorisk, med udfaldsmulighederne rigtig og forkert. ${ }^{11}$ Artiklens omfang tillader ikke en udførlig beskrivelse af resultaterne i forbindelse med de enkelte forståelsesspørgsmål, så vi vil her nøjes med at se på effekten af Brevversion selvom der i de fleste tilfælde også er andre signifikante variable i de modeller der er tale om.

For de fleste af spørgsmålenes vedkommende, F2, F3, F4, F5, F6 og F7, bekræftes hypotesen vedrørende Brevversion idet V2 medfører en signifikant større sandsynlighed for korrekt svar end V1. Også for F1's vedkommende medfører V2 en større sandsynlighed for korrekt svar. P-værdien er her 0,0124, hvilket normalt anses for at være signifikant; men eftersom vi her kan siges at teste samme hypotese otte gange, bør der foretages en såkaldt Bonferroni-korrektion for at tage højde for sandsynligheden for et falsk positivt resultat, altså at man postulerer en forskel der ikke er der. Herved skal p-værdien være otte gange lavere end normalt (dvs. $0,05 / 8=0,00625)$ før effekten kan siges at være signifikant, hvilket altså ikke er tilfældet for F1's vedkommende. For F3 og F6's vedkommende (men ikke for de øvrige spørgsmål) var der, ligesom det var tilfældet for forståelsesindekset, signifikante interaktioner

11 Analyserne blev udført i R (version 3.3.1) med funktionen $l r m$ i pakken $r m s$, version 4.5-0. 
med LScore således at der kun ses positive effekter af omskrivningen hos de svageste læsere. For F6's vedkommende er der ligefrem en negativ effekt af omskrivningen hos de bedste læsere, således at forståelsen af V1 faktisk samlet set er bedre end af V2 (se Figur 3 som viser en sammenligning af de to brevversioner mht. andelen af rigtige svar for hvert af de otte forståelsesspørgsmål).

FIGUR 3. SAMMENLIGNING AF DE TO BREVVERSIONER

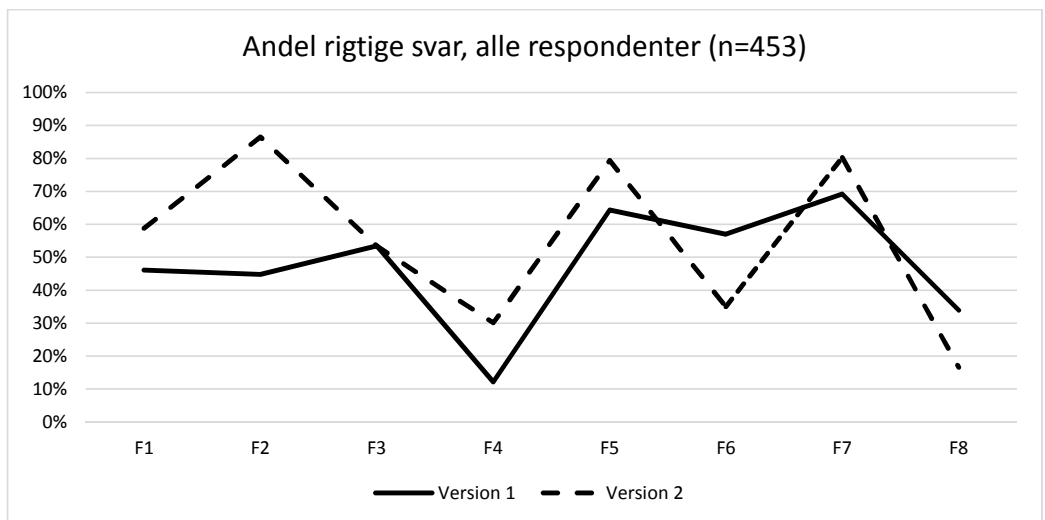

Bemark at der her, i modsatning til i regressionsanalyserne, ikke tages hensyn til effekten af de ovrige uafhangige variable, herunder respondenternes lasescore, bvilket skjuler at der faktisk er en positiv effekt af omskrivningen for de svageste lasere i forbindelse med F3 og F6.

Også i forbindelse med F8 er der en signifikant effekt af Brevversion $\left(\mathrm{p}<0,0001 ;\right.$ der er her ingen signifikant interaktion med LScore),${ }^{12}$ men som Figur 3 også indikerer, er effekten den omvendte af det forventede: Der er større sandsynlighed for korrekt svar når respondenterne læser V1 end når de læser V2.

Ovenstående resultater rejser naturligvis spørgsmålet hvad der ved hvert af de otte forståelsesspørgsmål lader til at gøre den ene tekstversion lettere at forstå end den anden. Det er vigtigt at understrege at undersøgelsen ikke blev designet for at afgøre hvilken betydning bestemte tekstlige faktorer har for tekstforståelsen, hvilket indebærer at spørgsmålene ikke entydigt relaterer sig til en bestemt ændring i brevet,

12 Koefficienten er -0,9478 logodds. De øvrige signifikante variable i denne model er LScore og Uddannelse. 
ligesom der kun er ca. ét teksteksempel og ét spørgsmål til at belyse en given ændringstype. Alligevel mener vi at resultaterne indikerer hvilke faktorer har betydning for forståelsen. Vi vil i den følgende gennemgang tage udgangspunkt i de spørgsmål der bekræfter vores hypotese $\mathrm{om}$ at V2 er lettere at forstå end V1. Til sidst behandler vi resultaterne af de to spørgsmål (F1 og F8) der ikke bekræftede denne hypotese.

\section{Omskrivning af vanskelige ord til mindre vanskelige ord eller parafraser oger for- ståelsen}

Resultaterne i forbindelse med især F4 og F7 antyder at nogle forståelsesproblemer kan løses ved simpelt hen at omformulere indholdet $\mathrm{i}$ hver enkelt sætning. Spørgsmålenes ordlyd, det rigtige svar og de tekstpassager hvor svaret kan findes, er gengivet nedenfor:

F4: Hvad kan der ske hvis du begynder at få mindre i løn end du gør i øjeblikket? Rigtigt svar: SKAT kan begynde at trække et mindre beløb uden at give dig besked.

\section{Tekstpassager hvor svaret kan findes:}

V1: Hvis dine indkomstforhold ændrer sig, før eller efter iværksættelsen af lønindeholdelsen, kan vi ændre lønindeholdelsesprocenten. En forhøjelse vil først ske efter et nyt varsel.

V2: Hvis din indkomst ændrer sig på et senere tidspunkt, kan vi ændre den procent, vi trækker i din løn. Hvis vi vil forhøje procenten, sender vi dig et brev.

F7: I hvilken situation skal du indsende et budgetskema?

Rigtigt svar: Hvis du mener du ikke kan betale det beløb SKAT har beregnet at du skal betale.

\section{Tekstpassager hvor svaret kan findes:}

V1: Hvis du mener, at lønindeholdelsen ikke giver dig og din eventuelle husstand et rimeligt rådighedsbeløb, skal du inden 15 dage udfylde og returnere det vedlagte budgetskema.

V2: Hvis du mener, at du ikke har et rimeligt beløb til rådighed fremover, skal du udfylde det budgetskema, vi har vedlagt, og sende det til os inden 15 dage.

V2 var i begge tilfælde lettest at forstå. De mest iøjnefaldende ændringer fra V1 til V2 vedrører håndteringen af nogle af de temmelig vanske- 
lige ord der optræder i V1, dvs. ord der må formodes at være sjældent forekommende og/eller morfologisk komplekse. "Indkomstforhold" er fx blevet til "indkomst", og "returnere" er blevet til "sende" i V2. Den temmelig lange sammensætning "lønindeholdelsesprocenten" er blevet opløst til et substantivsyntagme med relativsætning ("den procent, vi trækker i din løn"), og "forhøjelse" er blevet parafraseret til en aktiv betingelsesledsætning ("hvis vi vil forhøje procenten") i V2. Det tyder på at den sproglige rådgivnings traditionelle råd om at man bør undgå vanskelige ord (se fx Møller og Hansen 1981: 6-7), faktisk har en betydning for tekstforståelsen. Dog er det vigtigt at understrege at vi på grundlag af undersøgelsen ikke kan afgøre hvad det præcis er der gør ordene i V1 vanskelige. Søgninger i Dansk Sprognævns avistekst-korpus ${ }^{13}$ viser at to af ordene i V1 (returnere og indkomstforbold) er væsentligt mindre hyppige end de ord de er blevet erstattet med i V2. Returnere forekommer 438 gange i avistekst-korpusset, mens sende (som det erstattes med i V2) forekommer 20.156 gange. Indkomstforbold forekommer 42 gange, mens indkomst (som der står i V2) forekommer 4.471 gange. Lonindeholdelsesprocent og forbojelse i V1 erstattes ikke med et bestemt ord i V2, de er derimod parafraseret, og det er derfor ikke til at søge på det præcise ord de er blevet erstattet med. Vores søgninger i Dansk Sprognævns avistekst-korpus resulterede dog ikke i en eneste forekomst af lonindeholdelsesprocent. Ordet er altså tilsyneladende meget sjældent. Det forholder sig anderledes med forbojelse. Verbalsubstantivet erstattes med en sætning der indeholder verbet forboje, i V2 ("hvis vi vil forhøje procenten"), og det virker efter vores bedste overbevisning rimeligt at sammenligne frekvensen af forbojelse og forboje. De to ord lader til at være nogenlunde lige (lav)frekvente: Forbojelse forekommer 785 gange, og forbøje forekommer 648 gange. Hvad angår de tre øvrige ord, kunne det dog tyde på at frekvens har en betydning for forståelsen: I to tilfælde er "erstatningsordene" i V2 mere frekvente end ordene i V1, og et enkelt af ordene i V1 lader til at være meget sjældent i og med at det ikke forekommer en eneste gang i Sprognævnets avistekst-korpus. ${ }^{14}$

13 Dansk Sprognævns avistekst-korpus består af et udvalg af danske avistekster fra 2004 til 2016. Der medtages løbende nye avistekster i korpusset. I de søgninger der henvises til her, er der søgt i tekster fra landsdækkende aviser (Information, Kristeligt Dagblad, Politiken, JyllandsPosten, Berlingske og Weekendavisen) fra 2004-2016 (ca. 250 millioner løbende ord).

14 Det er vanskeligt at opstille kriterier for hvad der gør et ord sjældent (fx er verden fuld af 
Tre af de fire ord er imidlertid også mere morfologisk komplekse end de tilsvarende ord i V2 (det gælder dog ikke returnere, der ikke er mere morfologisk komplekst end sende). Der er således stort sammenfald mellem de to faktorer, og vi kan ikke afgøre om det er ordenes frekvens eller morfologiske kompleksitet der gør dem vanskelige.

Resultatet understøttes i øvrigt af den eksisterende forskning, se fx Campbell (1999: 349), der skriver at "simplifying the words used may enhance comprehension" (det er uklart om Campbell skelner mellem morfologisk kompleksitet og frekvens, jf. 1999: 343), og Wengelin (2015), der konkluderer at højfrekvente ord er lettere at forstå end lavfrekvente.

\section{Informationsudvalgelse påvirker forstålsen}

Resultaterne for F2, F5 og F6 antyder at informationsudvælgelse har betydning for forståelsen.

Svaret på F2 ("Hvor meget skylder du ifølge brevet SKAT?") formidles forskelligt i de to versioner. I V1 er den totale gældssum ikke nævnt $\mathrm{i}$ brevet, i stedet præsenteres læseren for to beløb der skal lægges sammen for at få den samlede gældssum. ${ }^{15} \mathrm{I}$ V2 præsenteres den samlede gældssum $i$ en tabel $i$ begyndelsen af brevet. V2 er lettest at forstå. Det er altså muligt at udvælgelsen af informationer (den samlede sum fremfor to beløb der skal lægges sammen, dvs. læseren skal slutte sig til en oplysning på grundlag af andre oplysninger) har betydning for forståelsen. Denne pointe understøttes af Swaney et al. (1991: 182 ff.) der påpeger at vanskeligheder med at forstå tekster kan hænge sammen med vanskeligheder med at drage slutninger på grundlag af de informationer læseren får i teksten.

I forbindelse med F5 lader informationsudvælgelsen også til at spille en rolle. Spørgsmål og rigtigt svar lyder:

mange andre slags tekster end avistekster), og det er langt uden for denne artikels formål at give sig i kast med en sådan opstilling af kriterier. Vores pointe er alene at det på grundlag af undersøgelsens resultater og vores søgninger i Dansk Sprognævns avistekst-korpus virker rimeligt at have en formodning om at ords hyppighed spiller en rolle for hvor svære de er at forstå.

15 Se i øvrigt bilag 5 for en beskrivelse af hvordan der er skelnet mellem rigtige og forkerte svar på dette spørgsmål. 
F5: Hvor længe vil SKAT blive ved med at trække penge fra din indkomst?

Rigtigt svar: Indtil gælden er betalt tilbage.

Svaret kan i V1 findes i følgende tekstpassage:

Tilbagekaldelse af lønindeholdelsen

Lønindeholdelsen vil blive tilbagekaldt, når restancen er indfriet.

I V2 får læseren ikke nogen informationer om hvor længe SKAT vil blive ved med at trække penge fra modtagerens indkomst. Ikke desto mindre er der signifikant flere korrekte besvarelser på grundlag af V2 end på grundlag af V1.

Respondenterne kan formentlig klare sig uden informationen fordi de ved at man normalt afdrager på en gæld indtil den er betalt tilbage, jf. også Swaney et al.s fokus på læseres "prior knowledge" (1991: 181). Det betyder dog ikke at det at informationen overhovedet gives, nødvendigvis forringer forståelsen. Problemet i V1 kan også være den sproglige form: Flere af ordene kan forekomme vanskelige (lonindeholdelse, tilbagekalde, restance og indfri) og kan måske gøre læseren usikker på hvad der egentlig står, jf. forrige afsnit.

I F6 fandt vi en positiv effekt af omskrivningen hos de svageste læsere, men en negativ effekt hos de bedste læsere. Spørgsmål og rigtigt svar lyder:

F6: Hvad kan der ske hvis du sender et budgetskema til SKAT?

Rigtigt svar: Du kan komme til at betale mere, mindre eller det samme hver måned.

Svaret står i V1 i følgende tekstpassager:

Hvis du mener, at lønindeholdelsen ikke giver dig og din eventuelle husstand et rimeligt rådighedsbeløb, skal du inden 15 dage udfylde og returnere det vedlagte budgetskema. (...)

SKAT vil på baggrund af de indsendte oplysninger vurdere, om lønindeholdelse kan gennemføres og med hvilken lønindeholdelsesprocent. 
Hvis vurderingen af dit budget viser, at der kan foretages lønindeholdelse hos dig med en højere procent end angivet i dette varsel, kan SKAT foretage lønindeholdelse hos dig med den højere procent.

I V1 står det tydeligt (se det sidste afsnit ovenfor) at SKAT kan trække en større del af modtagerens indkomst hvis man indsender budgetskemaet. Det får man imidlertid ikke at vide i V2 hvor læseren til gengæld får at vide at man skal indsende budgetskemaet "[h]vis du mener, at du ikke har et rimeligt beløb til rådighed fremover".

Vi finder det lettest at forklare hvorfor der var en negativ effekt af omskrivningen blandt de bedste læsere. Det virker nærliggende at antage at dygtige læsere forholder sig til de informationer der faktisk gives i teksten. I V1 står det tydeligt at man kan komme til at betale mere hvis man indsender budgetskemaet. V2 er mindre utvetydig, og ud fra de informationer der gives i teksten, kan læseren måske få indtryk af at budgetskemaet er reserveret til en situation hvor man ikke har et rimeligt beløb til rådighed - og at man derfor ikke kan komme til at betale mere om måneden hvis man indsender budgetskemaet.

Hvad angår de svage læsere, kunne man have en formodning om at de (eftersom de ikke er lige så gode til at læse teksten) i højere grad tyr til at gætte på det der virker mest sandsynligt. Og måske virker det faktisk mest sandsynligt at man kan komme til at betale mere, mindre eller det samme hvis man indsender budgetskemaet. Det forklarer imidlertid ikke hvorfor de svage læsere har gavn af omskrivningen. Hvis de under alle omstændigheder gætter løsrevet fra teksten, så burde det jo ikke gøre en forskel om de baserer deres gæt på V1 eller V2. En mulig forklaring er at store dele af V2 faktisk er lettere at forstå end V1. Det efterlader muligvis læserne af V2 med lidt mere overskud til at komme med et kvalificeret gæt - hvor V1 muligvis er så anstrengende at læse for svage læsere at de i højere grad mister overblikket over brevet og svarmulighederne.

Vigtigheden af informationsudvælgelse betones af Gunnarsson (1983). Hun påpeger bl.a. at tekstforståelse er påvirket af "det grundläggande urvalet och den grundläggande struktureringen av fakta" i teksten (1982: 83). Hvis man skal gøre en forskel for læsernes forstå- 
else, er det altså elementer som informationsudvælgelse (og strukturering af fakta, se næste afsnit) der skal bearbejdes.

\section{Informationsstrukturering paivirker forståelsen}

Struktureringen af informationer synes at have betydning i i hvert fald ét tilfælde, nemlig i forbindelse med besvarelsen af F3, hvor det dog vel at mærke kun er de svageste læsere der har gavn af omskrivningen. Spørgsmål F3 lyder: "Hvor stammer din gæld fra ifølge brevet?". I V2 fremgår svaret af et skema først i brevet. Det kan tyde på at selve skemaet er en hjælp for de svage læsere. Det kan dog også være at det ikke er selve skemaet i V2 der gavner de svage læsere, men snarere at informationerne er struktureret uhensigtsmæssigt i V1 - et problem der sagtens kunne være afhjulpet på andre måder end ved at indsætte et skema. I V1 nævnes parkeringsafgiften allerede i brevets hovedoverskrift, mens restskatten først introduceres i den løbende brevtekst. To lige vigtige informationer fremhæves altså i forskellig grad, og respondenterne vægter dem måske derfor ikke lige højt. Vi kender ikke til forskning der direkte behandler denne pointe, men problemstillingen knytter an til Swaney et al.s fokus på attention management, dvs. problemer med at fokusere på den relevante information (1991: 183-184). Tematikken berøres også af Gunnarsson der nævner at struktureringen af fakta har betydning for forståelsen af en tekst (jf. 1982: 83).

\section{F1 (ingen signifikant forskel mellem de to versioner) og F8 (V1 lettest at forstä)}

Analysen viser at der ikke er signifikante forskelle hvad angår F1 ('Hvad betyder budgetskema her i brevet?"). Det korrekte svar ("Et skema hvor du skriver hvad du har af udgifter og indtægter") kan udledes af begge versioner og det vedlagte (identiske) budgetskema. I forhold til nogle af de andre spørgsmål (fx F5 hvor det i V2 slet ikke står at SKAT holder op med at trække i modtagerens indkomst når gælden er betalt tilbage, mens oplysningen står i V1) får man meget ens oplysninger om hvad et budgetskema er i de to breve. Med udgangspunkt i de oplysninger der gives i de to breve, havde respondenterne altså tilsyneladende ens forudsætninger for at besvare spørgsmålet. Et insignifikant resultat er derfor forventeligt. Som påpeget $\mathrm{i}$ analyseafsnittet var resultatet dog signifikant før det blev Bonferroni-korrigeret - V2 var lettere at forstå 
end V1. En mulig (om end noget spekulativ) forklaring på det er at der er et tilsvarende fænomen på spil som i forbindelse med F6: Samlet set er V2 lettere at forstå, og det kan være at læserne derfor har haft mere overskud til at udlede det rigtige svar.

Resultaterne for F8 er i modstrid med hypotesen om at V2 er lettere at forstå end V1. Analysen viser nemlig at det er lettere at besvare F8 på grundlag af V1 end på grundlag af V2.

Spørgsmålet lyder:

F8: Hvor på internettet kan du ifølge brevet læse de regler der ligger til grund for afgørelsen?

Et svar blev regnet som rigtigt hvis det omfattede de to hjemmesider der blev næunt i brevet, nemlig skat.dk og retsinfo.dk.

Læseren kunne finde svaret på spørgsmålet i følgende passager:

V1:

\section{Hvor kan jeg finde reglerne}

Du kan finde reglerne om lønindeholdelse på www.retsinfo.dk og $\mathrm{i}$ inddrivelsesvejledningen på www.skat.dk (Rådgiver $\rightarrow$ Juridiske vejledninger $\rightarrow$ Inddrivelsesvejledning).

\section{V2:}

\section{Love og regler}

Du kan finde love og regler i inddrivelsesloven og inddrivelsesbekendtgørelsen på www.retsinfo.dk og $\mathrm{i}$ inddrivelsesvejledningen på www.skat.dk $\rightarrow$ Rådgiver $\rightarrow$ Juridiske vejledninger $\rightarrow$ Inddrivelsesvejledning.

Så vidt vi kan se, er der to mulige forklaringer på resultatet. Den ene forklaring er at afsnittet i V1 simpelt hen er klarere formuleret. Overskriften er den mest markante forskel, og det kunne tyde på at overskrifter formuleret som spørgsmål (uanset at der mangler et spørgsmålstegn i V1) er bedre end overskriften i V2. Denne forklaring understøttes dog ikke af Jones et al. (2012: 340) der konkluderer at det ikke påvirker forståelsen om overskrifter formuleres som fremsættende udsagn eller 
som spørgsmål. Overskriften i V1 adskiller sig også fra V2 ved i det hele taget at være formuleret som en sætning, hvilket også kunne være en mulig forklaring på den højere grad af forståelse af passagen.

En anden forklaring er at resultatet er udtryk for en metodisk svaghed ved undersøgelsen. Spørgsmålet "Hvor på internettet kan du ifølge brevet læse de regler der ligger til grund for afgørelsen?" minder nemlig mere om overskriften i V1 end om overskriften i V2. Både spørgsmålet og overskriften i V1 er formuleret som spørgsmål, og ordene "hvor" og "kan" indgår i både spørgsmålet og i overskriften i V1; det kan have gjort det lettere for læsere af V1 at besvare spørgsmålet.

\section{KONKLUSION OG PERSPEKTIVER}

Formålet med undersøgelsen var at vurdere betydningen af at forbedre forståeligheden af et brev fra en offentlig myndighed med henblik på de tre hypoteser 1) den omskrevne version er lettere at forstå end den oprindelige version, 2) alder, køn, modersmål og generelle læsefærdigheder har betydning for forståelsesniveauet, samt 3) omskrivningen har større betydning for svage "forståere" end for gode "forståere".

Undersøgelsen bekræftede stort set alle hypoteserne: Den omskrevne version var lettere at forstå end den oprindelige version, og de undersøgte læserkarakteristika havde den forventede effekt på forståelsen med undtagelse af køn som ikke havde nogen signifikant effekt. Hvad angår hypotesen om at den omskrevne version betød mere for de svage "forståere", viste analysen at det kun var respondenternes læsescore der interagerede med brevversionen: Personer med en lav læsescore havde signifikant bedre forståelse af den reviderede version end de gode læsere (mens de bedste læsere var lige gode til at forstå de to versioner).

Analysen af de otte forstålsesspørgsmål hver for sig bekræftede for de seks' vedkommende at V2 var signifikant lettere at forstå end V1. Dog gjaldt det for to af spørgsmålene at der kun er en statistisk signifikant forskel for de svageste læsere, ikke for respondentgruppen som helhed. De ændringer i teksten som særligt synes at være med til at højne forståelsen, var omskrivning af "vanskelige" ord til mindre 
vanskelige ord eller parafraser, informationsudvælgelse og informationsstrukturering.

Skal man pege på de perspektiver der åbner sig i forlængelse af denne artikel, er det værd at hæfte sig ved at der er ganske langt fra disse faktorer til formuleringen af retningslinjer for hvordan man som offentlig myndighed bør skrive til almindelige borgere. Ganske vist lader det til at det øger forståelsen hvis man fjerner vanskelige ord fra teksterne, og det er i fin overensstemmelse med de klassiske skriveråd. På grundlag af denne undersøgelse kan det dog ikke afgøres hvad det præcist er der gør et ord vanskeligt. Vores resultater peger på at det både kan hænge sammen med at ordene er sjældne, og med ordenes morfologiske kompleksitet. Hvilken rolle de to faktorer hver især spiller, kan dog ikke afgøres på grundlag af denne undersøgelse. Det vil også kræve yderligere forskning nærmere at indkredse hvordan informationsudvælgelse og informationsstrukturering påvirker forståelsen. Er det fx mest hensigtsmæssigt at redegøre for gældsposterne ved at opstille dem i et skema, eller kunne det gøres lige så hensigtsmæssigt (eller måske bedre) på andre måder? Hvad er det for en type informationer man helt kan eller bør udelade, og ville det øge forståelsen yderligere hvis man tog dem med $\mathrm{i}$ brevet $\mathrm{i}$ en sproglig form der var lettere tilgængelig end det er tilfældet i V1? Det leder til et mere principielt spørgsmål, nemlig hvor specifikke retningslinjer for tekstskrivning man meningsfuldt kan opstille for arbejdet med at gøre tekster fra offentlige myndigheder lettere at forstå. Ville man med rimelighed kunne opstille en anvisning om at bestemte typer informationer som hovedregel altid bør fremstilles i tabelform? Eller er samspillet mellem elementer som tekstens indhold, kontekst, form og modtageren så komplekst at det som hovedregel ikke lader sig gøre at opstille specifikke anvisninger (som der ellers har været en vis tradition for) for hvordan man bør skrive?

Der er altså nok at tage fat på i arbejdet med at undersøge det empiriske belæg for bestræbelsen på at gøre tekster fra offentlige institutioner lettere at forstå. Det er dog værd at hæfte sig ved at den reviderede version faktisk er lettere at forstå for læserne. Selvom vi er langt fra at kunne opstille præcise, empirisk funderede retningslinjer for hvad det faktisk er der øger forståelsen, så tyder det på at tekstarbejdet i offentlige institutioner faktisk gør en positiv forskel for borgerne. 


\section{TAKSIGELSER}

Tak til alle de lærere der lod Anne Kjærgaard komme på besøg i deres klasser og gennemføre undersøgelsen, og til alle de studerende, elever og kursister der deltog i undersøgelsen. Tak til de medarbejdere i SKAT, særligt Christina Holgård Sørensen, der på forskellig vis har bidraget til undersøgelsen. Og tak til Katrine Mølholm, Dansk Sprognævn der stod for at indtaste de udfyldte spørgeskemaer.

Anne Kjærgaard

Dansk Sprognævn

akjaergaard@dsn.dk
Torben Juel Jensen

Institut for Nordiske Studier og Sprogvidenskab Københavns Universitet

tjuelj@hum.ku.dk 


\section{LITTERATUR}

Arnbak, E. 2001. Lasetekster for unge og voksne. København: Dansk psykologisk Forlag.

Balling, L.W. 2013. Does good writing mean good reading? An eye-tracking investigation of the effect of writing advice on the reading process. Fachsprache 35. 2-23. http://www.fachsprache.net/upload/Balling_Does_Good_Writing_Mean_ Good_Reading_1-2_2013.pdf. (Tilgået 28. juli, 2016.)

Bartell, A.L., L.D. Schultz \& J.H. Spyridakis, 2006. The effect heading frequency on comprehension of print versus online information. Technical communication 53(4). 416-426. http://faculty.washington.edu/jansp/Publications/HeadingsPrintOnline.pdf. (Tilgået 28. juli, 2016.)

Bendegard, S. 2015. Klarspråksarbetets villkor i samband med EU:s rättsaktsöversättning. Sakprosa 7(2). https://www.journals.uio.no/index.php/sakprosa/article/view/981. (Tilgået 16. juni, 2016.)

Bolius (Boligejernes Videncenter, 2013) Mandene bestemmer over boliglanet. https:/ /www.bolius.dk/maendene-bestemmer-over-boliglaanet-4427/. (Tilgået 28. juli, 2016.)

Campbell, N. 1999. How New Zealand consumers respond to plain English. Journal of business communication 36. 335-358. DOI: 10.1177/002194369903600402.

Davis, J. 1977. Protecting consumers from overdisclosure and gobbledygook: an em pirical look at the simplification of consumer-credit contracts. Virginia law review 63(6). 841-920. DOI: 10.2307/1072522.

Demarmels, S., D. Schaffner, S. Kolberg \& A. Janoschka 2013. Ökopower oder Naturstrom? Handlungsempfehlungen für eine verständliche Marketingkommunikation von Stromprodukten aus erneuerbaren Energien. Hochschule Luzern - Wirtschaft, Institut für Kommunikation und Marketing IKM. http://blog.hslu.ch/verstaendlichkeit/files/2012/07/HSLU_Oekopower-Naturstrom_Schlussbericht.pxdf. (Tilgået 16. juni, 2016.)

Dickinson, D., D.K. Raynor \& M. Duman 2001. Patient information leaflets for medicines: using consumer testing to determine the most effective design. Patient education and counselling 43. 147-159. DOI: 10.1016/S0738-3991(00)00156-7.

Elbro, C., S. Møller \& E. M. Nielsen 1995. Functional reading difficulties in Denmark. A study of adult reading of common texts. Reading and writing. An interdisciplinary journal 7. 257-276.

Gogolok, K. 2005. Die Verwaltungssprache als Untersuchungsgegenstand linguisticher und interdisziplinärer Analysen: Theorie und Praxis. Fachsprache. International journal of LSP 27(3-4). 99-114. 
Gunnarsson, B.L. 1982. Lagtexters begriplighet. En språkfunktionell studie av medbestämmandelagen. Lund: LiberFörlag.

Hansen, E. 1971. Ping- og pampersprog. København: Hans Reitzels Forlag.

Höög, C.N., H. Söderlundh \& M. Sörlin 2012. Myndigheters texter och klarspråksarbete. Höög, C.N., H. Söderlundh \& M. Sörlin (red.), Myndigheterna har ordet. Om kommunikation i skrift, 13-38. Stockholm: Språkrådet og Nordstedts.

Ingemansson, J.M. \& T.J. Jensen 2015. Passiven bør undgås - eller bør den? En receptionsundersøgelse af passivers indflydelse på forståelse af og holdninger til breve fra en offentlig myndighed. NyS 49. 123-165.

Jansen, C. \& M. Steehouder 2001. How research can lead to better government forms. D. Janssen \& R. Neutelings (red.), Reading and writing public documents. Problems, solutions and characteristics, 11-36. Amsterdam: John Benjamins Publishing Company. http://begrijpelijkeformulieren.org/sites/begrijpelijkeformulieren/ files/Jansen_How_research_can_lead_to_better_government_forms.pdf. (Tilgået 28. juli, 2016.) DOI: 10.1075/ddcs.1.02jan.

Jansen, F. 2001. The lack of clarity in a sentence. The style of official documents in Dutch.

Janssen, D. \& R. Neutelings (red.), Reading and writing public documents. Problems, solutions and characterstics, 125-145. Amsterdam: John Benjamins Publishing Company. DOI: 10.1075/ddcs.1.07jan.

Janssen, D. \& R. Netuelings 2001. Introduction. D. Janssen \& R. Neutelings (red.), Reading and writing public documents. Problems, solutions and characteristics, 1-9. Amsterdam: John Benjamins Publishing Company. DOI: 10.1075/ddcs.1.01jan.

Jensen, L.B. 1998. Kancellistil eller Anders And-sprog? - en undersogelse af forvaltningssproget og dets institutionelle betingelser. Frederiksberg: Roskilde Universitetsforlag.

Jensen, L.B., A. Kjærgaard, M. Krone \& C.H. Sørensen 2014. Find dit teoretiske udgangspunkt. C.H. Sørensen (red.), Godt sprog $i$ organisationer - veje til vellykket sprogarbejde, 13-42. København: Hans Reitzels Forlag.

Jones, N., J. McDavid, K. Derthick, R. Dowel \& J. Spyridakis 2012. Plain language in environmental policy documents: an assessment of reader comprehension and perceptions. Journal of technical writing and communication 42(4). 331-371. DOI: http://dx.doi.org/10.2190/TW.42.4.b

Kimble, J. 2012. Writing for dollars, writing to please. The case for plain language in business, government and law. North Carolina: Carolina Academic Press.

Kjærgaard, A. (Under udgivelse). "Revising real world tax management speak - a study of reader response". Fachsprache. 
Kjærgaard, A. 2015a. Påvirker omskrivninger af tekster fra det offentlige borgernes forståelse - og hvordan? Sakprosa 7(2). 1-25. https://www.journals.uio.no/index.php/sakprosa/article/view/793 (Tilgået 16. juni, 2016.)

Kjærgaard, A. 2015b. På borgernes præmisser? Revision af borgerrettede tekster hos SKAT. Skandinaviske sprogstudier 6(4). 43-65. http://ojs.statsbiblioteket.dk/index.php/sss/article/view/22984 (Tilgået 5. juni, 2016)

Kjærgaard, A. 2014. Fra "Varsel om lønindeholdelse" til "SKAT vil trække i din løn" - hvad foretrækker borgerne? Nyt fra Sprognavnet 2014(2). 13-20. https://dsn. $\mathrm{dk} /$ nyt/nyt-fra-sprognaevnet/nyt $\% 20 \mathrm{fra} \% 20$ sprognaevnet $\% 202 \% 2014 \% 20$ web.pdf (Tilgået 28. juli, 2016.)

Kjærgaard, A. 2013. Hvad mener du, SKAT? Modtageranalyser af breve fra SKAT. I.S. Hansen, T.T. Hougaard og P. Widell (red.), 14. Mode om udforskningen af dansk sprog, 217-236. Aarhus: Aarhus Universitet. http://muds.dk/rapporter/ MUDS_12.pdf (Tilgået 28. juli, 2016.)

Kjærgaard, A. 2010. Sådan skriver vi. Eller gor vi? - En undersogelse af de tekstlige effekter af to sprogpolitiske projekter $i$ Danmarks Domstole og Kobenhauns Kommune og af àrsagerne til projekternes gennemslagskraft. Ph.d.-afhandling. Københavns Universitet.

Kjøller, K. 2016. Bedre offentlig sprogbrug: Gode hensigter rammer grum virkelighed. Thingnes J. J.S. (red.), Fra myndig maktspräk til klar kommunikasjon. Rapport fra Nordisk klarspråkskonferanse Oslo 28.-29. maj 2015, 59-70. Netværket for sprognævnene i Norden. http://ojs.statsbiblioteket.dk/index.php/ksn/article/view/23922. (Tilgået 13. oktober 2016.)

Masson M.E.J. \& M.A. Waldron 1994. Comprehension of legal contracts by non-experts: effectiveness of plain language redrafting. Applied cognitive psychology 8. 6785. https://web.uvic.ca/psyc/masson/MW94.pdf. (Tilgået 28. juli, 2016.)

Møller, B. \& E. Hansen 1981. - og uden omsvob tak!Statens Informationstjeneste. https:/ / dsn.dk/sprogviden/sprogprojekter/linksamling-1/\%20og\%20uden \%20omsvoeb\%20tak.pdf. (Tilgået 28. juli, 2016.)

Nord, A. 2011. Att göra någon annans text tydlig. Förutsättningar och språkideal vid språkbearbetning av myndighetstext. (TeFa 48). Uppsala: FUMS, Institutionen för nordiska språk, Uppsala universitet. http://www.diva-portal.org/smash/get/ diva2:578975/FULLTEXT01.pdf. (Tilgået 28. juli, 2016.)

Pedersen, K. 2014. Plain language and organizational challenges. SAGE Open, AprilJune 2014. http://sgo.sagepub.com/content/4/2/2158244014539517. (Tilgået 16. juni, 2016.) DOI: $10.1177 / 2158244014539517$. 
Pedersen, K. 2004. When authorities communicate - democracy and local and regional Authorities. K. Nikula, K. Alanen \& H. Lönnroth (red.), Text, bild, sambälle, 213-226. Nordiska Språk, Institutionen för språk- och översättningsvetenskap, Tammerfors universitet.

Penge- og Pensionspanelet. 2010. Kvalitativ rapport om forstaelsen af realkreditinstitutternes skriftlige materiale blandt boligejere med rentetilpasningslan. Kan søges frem fra http:/ / www.raadtilpenge.dk/da/Forside.aspx. (Tilgået 29. juni, 2016.)

Petersen, D. K. 2008. Hvad har betydning for elevers laseforståelse? (Læserapport 44). Landsforeningen af Læsepædagoger.

Schriver, K. 2012. What we know about expertise in professional communication. Virginia Wise Berninger (red.), Past, present, and future contributions of cognitive writing research to cognitive psychology, 275-312. New York: Psychology Press.

Schriver, K. \& F. Gordon 2010. Grounding plain language in research. Clarity 64. 3339. http://clarity-international.net/journals/64.pdf. (Tilgået 16. juni, 2016.)

Solomon, N. 1996. Plain English: from a perspective of language in society. Ruqaia Hasan \& Geoff Williams (red.), Literacy in society, 279-307. London: Longman.

Steinberg, E.R. (red.) 1991. Plain language. Principles and practice. Detroit, MI: Wayne State University Press.

Swaney, J.H., C.J. Janik, S.J. Bond \& J.R. Hayes 1991. Editing for comprehension: improving the process through reading protocols. E.R. Steinberg (red.), Plain language. Principles and practice, 173-203. Detroit, MI: Wayne State University Press.

Søndergaard, Y. 2010. Sprogpolitik, passiver og kancellisløjfer. Nyt fra Sprognaunet 2010(2). 6-8. https://dsn.dk/nyt/nyt-fra-sprognaevnet/2010-2.pdf. (Tilgået 28. juli, 2016.)

Walmsley, S.A., K.M. Scott \& R. Lehrer 1981. Effects of document simplification on the reading comprehension of the elderly. Journal of reading behavior 13(3). 237-248. http://jlr.sagepub.com/content/13/3/237.full.pdf. (Tilgået 28. juli, 2016.) DOI: $10.1080 / 10862968109547411$.

Wengelin, A. 2015. Mot en evidensbaserad språkvård? En kritisk granskning av några svenska klarspråksråd i ljuset av forskning om läsbarhet och språkbearbetning. Sakprosa 7(2). https://www.journals.uio.no/index.php/sakprosa/article/ view/983. (Tilgået 16. juni, 2016.)

Wille, N.E. 2001. Det gode sprog. Nogle tanker om det forskningsmæssige grundlag for rådgivning om sproget i faglig formidling. L. Heltoft og C. Henriksen (red.), Den analytiske gejst. Festskrift til Uwe Geist på 60-årsdagen 23. september 2001, 259271. Frederiksberg: Roskilde Universitetsforlag. 
Wismar, M. 2010. Hvor skeriver vi hen? - en undersogelse af fem sprogguider til organisationskommunikation. Speciale. Roskilde Universitet. http://www.rucsdigitaleprojektbibliotek.dk/handle/1800/5515. (Tilgået 28. juli, 2016.) 


\section{BILAG 1: BREVVERSION 1}

\section{Varsel om lønindeholdelse til dækning af parkeringsafgift m.fl.}

Du har ikke reageret på vores tidligere henvendelse, og vi skal derfor meddele dig, at vi agter at foretage lønindeholdelse hos dig.

Restgælden på din parkeringsafgift udgør 1.010,00 kr. pr. dags dato. Restgælden på din restskat udgør på 5.665,00 kr. pr. dags dato.

\section{Lønindeholdelsesprocent}

Vi kan foretage lønindeholdelse hos dig med $10 \%$ efter reglerne i kapitel 5 i bekendtgørelse nr. 1365 af 19.12.2008 om inddrivelse af gæld til det offentlige (inddrivelsesbekendtgørelsen) jf. \ 10 i lov nr. 1333 af 19.12.2008 om inddrivelse af gæld til det offentlige (inddrivelsesloven).

Lønindeholdelsesprocenten vil blive lagt oven i din trækprocent på dit skattekort, og lønindeholdte beløb bliver indbetalt til SKAT samtidig med indbetalingen af din Askat.

\section{Fastsættelse af lønindeholdelsesprocenten}

Din betalingsevne er fastsat på baggrund af din årsindkomst, som er opgjort til $180.080,00 \mathrm{kr}$. Det er oplysninger fra indkomstregisteret for februar 2012 på 15.073,00 $\mathrm{kr}$, som er omregnet til en årsindkomst.

Du kan med denne indkomst betale $12 \%$ af den årlige nettoindkomst. Da lønindeholdelsen foretages over dit eSkattekort med en procentdel af din A-indkomst før skat, har vi foretaget en omregning af procenten til en lønindeholdelsesprocent på $10 \%$. Herved sikres, at der kun lønindeholdes det beløb, som du efter dine nettoindkomstforhold skal betale.

Beregningen af din lønindeholdelsesprocent er sket $\mathrm{i}$ henhold til $\ 5$, stk. $1 \mathrm{i}$ inddrivelsesbekendtgørelsen (bekendtgørelse nr. 1365 af 19. december 2008 om inddrivelse af gæld til det offentlige).

Hvis dine indkomstforhold ændrer sig, før eller efter iværksættelsen af lønindeholdelsen, kan vi ændre lønindeholdelsesprocenten. En forhøjelse vil først ske efter et nyt varsel.

\section{Budgetskema}

Hvis du mener, at lønindeholdelsen ikke giver dig og din eventuelle husstand et rimeligt rådighedsbeløb, skal du inden 15 dage udfylde og returnere det vedlagte budgetskema. Sammen med budgettet skal du vedlægge dokumentation for dine udgifter og kopi af de seneste tre lønsedler for hele din husstand. 
SKAT vil på baggrund af de indsendte oplysninger vurdere, om lønindeholdelse kan gennemføres og med hvilken lønindeholdelsesprocent.

Hvis vurderingen af dit budget viser, at der kan foretages lønindeholdelse hos dig med en højere procent end angivet i dette varsel, kan SKAT foretage lønindeholdelse hos dig med den højere procent. Du vil så modtage et nyt varsel fra SKAT inden vi træffer afgørelse om lønindeholdelse.

\section{Varslingsfrist}

Hvis du ikke inden de 15 dage indsender budgetskemaet, vil SKAT iværksætte lønindeholdelse hos dig i overensstemmelse med dette varsel. Du vil modtage en skriftlig afgørelse fra os med en klagevejledning i forbindelse med, at vi iværksætter lønindeholdelsen.

\section{Tilbagekaldelse af lønindeholdelsen}

Lønindeholdelsen vil blive tilbagekaldt, når restancen er indfriet. Vi skal gøre opmærksom på, at der kan blive lønindeholdt mere end restgældens størrelse i den måned, hvor din restance er færdigbetalt.

SKAT kan anvende et overskydende beløb til dækning af andre restancer, for hvilke der kunne være truffet afgørelse om lønindeholdelse, jf. inddrivelseslovens $\ 10$, stk. 7. Resterende beløb som ikke modregnes vil blive udbetalt til dig.

Selvom du begynder at modtage A-indkomst, der ikke kan foretages lønindeholdelse i, fx kontanthjælp og SU, jf. Inddrivelsesbekendtgørelsen $\ 12$ tilbagekalder SKAT ikke lønindeholdelsen. Lønindeholdelsen vil i denne situation blive inaktiv og vil først blive aktiv igen på det tidspunkt, hvor du modtager A-indkomst, der kan foretages lønindeholdelse i. Har din betalingsevne ændret sig på dette tidspunkt, skal du rette henvendelse til SKAT med henblik på at få foretaget en vurdering af din betalingsevne.

\section{Telefon eller selvbetjening}

Har du spørgsmål, kan du ringe til os på telefon 70157304 alle hverdage kl. 10 - 15. Du kan hele døgnet betjene dig selv på Selvbetjening restancer ved at vælge TastSelv Borger på www.skat.dk/selvbetjening.

\section{Hvor kan jeg finde reglerne}

Du kan finde reglerne om lønindeholdelse på www.retsinfo.dk og i inddrivelsesvejledningen på www.skat.dk (Rådgiver $\rightarrow$ Juridiske vejledninger $\rightarrow$ Inddrivelsesvejledning).

Med venlig hilsen

SKAT

Inddrivelsescentret 


\section{BILAG 2: BREVVERSION 2}

\section{SKAT vil trække i din løn som betaling på din gæld}

Vi har tidligere skrevet til dig, at du har en gæld. Da du ikke har betalt beløbet, forbereder vi dig på, at vi vil trække en del af din løn som betaling på gælden. Hvis du mener, at du ikke har et rimeligt beløb til rådighed, når vi trækker i din løn, kan du inden 15 dage udfylde og sende os det budgetskema, vi har vedlagt.

Du skylder følgende beløb:

\begin{tabular}{llllr} 
Gæld & Beskrivelse & Periode & Modtaget i SKAT & Beløb \\
\hline Restskat & & Forfald 1.10.2012 & 05.11 .2012 & $5.525,00$ \\
Rykkergebyr & & 17.11 .2012 & 17.11 .2012 & 140,00 \\
Parkeringsafgift & Parkering 345677 & 07.08 .2012 & 15.11 .2012 & 910,00 \\
& Oprettelsesgebyr & & & 100,00 \\
\hline I alt & & & & $\mathbf{6 . 6 7 5 , 0 0}$ \\
\hline \hline
\end{tabular}

Vi vil trække en procentdel af din løn

Vi vil trække $10 \%$ af din løn som betaling på gælden. Procenten bliver lagt oven i trækprocenten på dit skattekort, og beløbet bliver betalt til SKAT sammen med din A-skat. Du skal altså ikke selv gøre noget for at betale beløbet.

Du kan finde reglerne $\mathrm{i}$ inddrivelsesbekendtgørelsens kapitel 5 og $\mathrm{i}$ inddrivelseslovens $\int 10$.

\section{Du kan sende et budgetskema inden 15 dage}

Hvis du mener, at du ikke har et rimeligt beløb til rådighed fremover, skal du udfylde det budgetskema, vi har vedlagt, og sende det til os inden 15 dage. Sammen med budgetskemaet skal du sende dokumentation for dine indtægter og udgifter. Dokumentation for dine indtægter kan være kopi af lønsedler for de seneste tre måneder for dig selv og dem, du eventuelt lever sammen med. Dokumentation for dine udgifter kan være de regninger, du senest har betalt.

Når du har sendt materialet, vurderer vi igen, om vi vil trække i din løn. Vi sender dig herefter et nyt brev med vores afgørelse. Hvis du ikke sender os budgetskemaet inden 15 dage, trækker vi den procent af din løn, som vi har varslet i dette brev.

\section{Sådan fastsætter vi, hvor stor en procentdel af din løn vi trækker}

Vi har vurderet, hvad du kan betale på baggrund af din årsindkomst, som vi har opgjort til 180.880,00 kr. efter skat. Årsindkomsten har vi beregnet ud fra din årsopgørelse for 2011. 
Du skal med denne indkomst betale $12 \%$ af din årlige indkomst efter skat, og det svarer til, at vi trækker $10 \%$ af din A-indkomst for skat. Din A-indkomst før skat har vi opgjort til 25.826,00 kr.

Du kan finde reglerne i inddrivelsesbekendtgørelsens $\int 8$.

\section{Hvis din indkomst ændrer sig}

Hvis din indkomst ændrer sig på et senere tidspunkt, kan vi ændre den procent, vi trækker i din løn. Hvis vi vil forhøje procenten, sender vi dig et brev.

\section{Hvis du har spørgsmål}

Har du spørgsmål, er du velkommen til at kontakte SKAT Inddrivelsescentret på telefon 701573 04. Du kan hele døgnet orientere dig om din gæld på www.skat.dk $\rightarrow$ TastSelv Borger $\rightarrow$ Selvbetjening restancer.

\section{Love og regler}

Du kan finde love og regler i inddrivelsesloven og inddrivelsesbekendtgørelsen på www.retsinfo.dk og i inddrivelsesvejledningen på www.skat.dk $\rightarrow$ Rådgiver $\rightarrow$ Juridiske vejledninger $\rightarrow$ Inddrivelsesvejledning.

Med venlig hilsen

SKAT

Inddrivelsescentret 


\section{BILAG 3: BUDGETSKEMA (IDENTISK FOR DE TO BREV- VERSIONER)}

\section{Budgetskema til SKAT}

\begin{tabular}{|c|c|c|c|c|}
\hline Navn: & CPR-nr.: & \multicolumn{2}{|c|}{ Tif.nr.: } & \\
\hline Adresse: & Postnr:: & Byn: & ivn: & \\
\hline Gift eller samlevende $\square$ CPR.nr. & \multicolumn{4}{|c|}{ Falles folkeregisteradresse fra dato: } \\
\hline \multicolumn{2}{|l|}{ Indtagter pr. maned } & Egne $i \mathrm{kr}$. & $\begin{array}{l}\text { Fgtefalle/ } \\
\text { samlever } \mathrm{iks} \text {. }\end{array}$ & Total i kr: \\
\hline \multicolumn{5}{|l|}{ Nettoindkomst } \\
\hline \multicolumn{5}{|l|}{ Udbetaling fra pensionsordning $\& 14$, stk. $3, \mathrm{nr} .1$} \\
\hline \multicolumn{5}{|c|}{ Udbetalinger af erstatning for tab af erhvervsevne, tab af forsarger og lign $\$ 14$, stk. 3, nr. 2} \\
\hline \multicolumn{5}{|l|}{ Husstandens månedlige nettoindkomst $i$ alt } \\
\hline \multicolumn{2}{|l|}{$\begin{array}{l}\text { Udgifter pr. måned } \\
\text { Befordring, transport mv. } \S 14, \text { stk. } 4 \text {, nr. } 3-6\end{array}$} & Egne i kr. & $\begin{array}{l}\text { Agtefalle / } \\
\text { samlever i kr. }\end{array}$ & Total i kr. \\
\hline \multicolumn{5}{|l|}{ Udgifter til offentlig transport til og fra arbejde } \\
\hline \multicolumn{5}{|c|}{$\begin{array}{l}\text { Udgifter til bil - transport til og fra arbejde kan medtages under sæerlige omstzendigheder } \\
\text { (specifikation skal vedlægges) }\end{array}$} \\
\hline \multicolumn{5}{|l|}{ Fagforening/bidrag til efterlønsordning } \\
\hline \multicolumn{5}{|l|}{ Bidrag til et trossamfund (ikke folkekirken) } \\
\hline \multicolumn{5}{|l|}{ Boiigudgifter $\$ 15$} \\
\hline \multicolumn{5}{|l|}{ Husleje } \\
\hline \multicolumn{5}{|l|}{ Prioritetsydelse (terminsydelse) } \\
\hline \multicolumn{5}{|l|}{ Frellesudgifter vedr. ejendom } \\
\hline \multicolumn{5}{|l|}{ Ejendomsskat og ejendomsvardiskat } \\
\hline \multicolumn{5}{|l|}{ El, gas, vand, varme, renovation mv. } \\
\hline \multicolumn{5}{|l|}{ Bygnings- og brandforsikring } \\
\hline \multicolumn{5}{|l|}{ - boligsikring / boligydelse } \\
\hline \multicolumn{5}{|l|}{ - varmetilskud mv. } \\
\hline \multicolumn{5}{|l|}{ Andre udgifter } \\
\hline \multicolumn{5}{|l|}{ Egtefellebidrag \$18 (alene fastsat beløb af statsamtet) } \\
\hline Bemebidrag \$ 18 (alene normal bidrag) & & & & \\
\hline Udgifter til samvar med berns samvar med anden foræeldre $\$ 16$ stk. $3 \mathrm{nr}$. & & & & \\
\hline Samvarsudgifter med børn under 18 ăr. (ikke hjemmeboende/specifikatic & ion vedlagges) $\$ 17$ & & & \\
\hline $\begin{array}{l}\text { Nettoudgift til særlige behov (nødvendige udgifter til medicin, behandlins } \\
\text { (invalide bil) mv.) } \$ 19 \text { og } \$ 20\end{array}$ & nger, transport & & & \\
\hline $\begin{array}{l}\text { Ydelse på ægtefalle / samlevers gald (Ikke falles gald og ikke udgifter } \\
\text { og transportmiddel) } \$ 22\end{array}$ & til nuvarende bolig & & & \\
\hline Anvendt til & -ảảăă & & & \\
\hline 2. & & & & \\
\hline 3. & & & & \\
\hline Ydelse pa privat geld der vedrerer erhvervelser omfattet af retsplejeloven & ens \& $509 . \$ 23$ & & & \\
\hline $\begin{array}{l}\text { Kreditor } \\
1 .\end{array}$ & ăăa & & & \\
\hline 2. & & & & \\
\hline $\begin{array}{l}\text { Er din gald i det vesentligste opstäet for samliv, eller traffes der samtidig af } \\
\text { gxldssaneringskendelse vedr, din agtefielle/samlever, eller afdrager agtefell }\end{array}$ & $\begin{array}{l}\text { fgorelse om eftergivelse } \\
\text { lle/samlever pá offentli }\end{array}$ & $\begin{array}{l}\text { eller afsiges der } \\
\text { gacld. (sat X) }\end{array}$ & samtidig & $\square$ \\
\hline Udgifter til hjemmeboende bern (under 18 àr) pr. måned $\$ 16$ & Barn 1 & Barn 2 & Barn 3 & Barn 4 \\
\hline Barnets alder & ằr & àr & àr & ăr \\
\hline Indtagter & & & A & At \\
\hline Bømefamilieydelse & & & & \\
\hline Bemetilskud & & & & \\
\hline Bomebidrag & & & & \\
\hline Udgifter & & & & \\
\hline Pasning & & & & \\
\hline $\begin{array}{l}\text { Udgifter til saerlige behov (nødvendige udgifter til medicin, behandlinger } \\
\text { transport } \mathrm{mv} \text {.) }\end{array}$ & & & & \\
\hline
\end{tabular}

Dokumentation for anforte indtagter ( 3 sidste lensedler) samt anforte udgifter (sidste betalte regning) skal vedlagges.

Jeg anmoder om, at min afdragsordning/lenindeholdelse fastsettes efter en konkret betalingsevnevurdering, og jeg er opmaerksom pa, at dette kan medfore et højere afdrag, et lavere afdrag eller samme afdrag som det fastsatte afdrag eller den varslede / igangverende lonindeholdelse.

Jeg er bekendt med, at det alene er udgifter, som udtrykkeligt er omtalt i inddrivelsesbekendtgerelsen, der vil indgå i SKATs vurdering. Det betyder, at fx udgifter til telefon, licens, indboforsikring, forbrugslan mv. ikke vil indga i vurderingen.

Dato: Underskrift: Yderligere information kan findes i bekendtgorelse om inddrivelse af greld til det offentlige.
Blanket nummer - 51.054 


\section{BILAG 4: FORSTÅELSESSPØRGSMÅL (F1-F8)}

(Den korrekte svarmulighed er understreget)

\section{F1: Hvad betyder budgetskema her i brevet?}

(Ordet er overstreget med gront i brevet. Sat kun 1 kryds)

- Et skema hvor du lægger en plan for hvordan du vil bruge dine penge mens du betaler af på din gæld til SKAT

- Et skema hvor du skriver hvad du har af udgifter og indtægter i en 3-måneders periode

- Et skema hvor du skriver hvad du har af udgifter og indtægter

- Et skema hvor du skriver hvad du har af udgifter og indtægter i en 6-måneders periode

- Ved ikke/andet (skriv gerne hvad)

\section{F2: Hvor meget skylder du ifølge brevet SKAT?}

Skriv svaret her:

\section{F3: Hvor stammer din gæld fra ifølge brevet?}

Skriv svaret her:

F4: Hvad kan der ske hvis du begynder at få mindre i løn end du gør for øjeblikket?

(Sat kun 1 kryds)

- Det vil aldrig have nogen betydning for hvor meget du skal betale af på din gæld

- SKAT kan forhindre dig i at modtage penge fra det offentlige, fx kontanthjælp og SU

- SKAT kan begynde at trække et mindre beløb, men først når de har givet dig besked

- $\underline{\text { SKAT kan begynde at trække et mindre beløb uden at give dig besked }}$

- Ved ikke/andet (skriv gerne hvad)

F5: Hvor længe vil SKAT blive ved med at trække penge fra din indkomst?

(Sat kun 1 kryds)

- Indtil du har betalt din gæld og et obligatorisk ekstrabeløb der kan dække fremtidig gæld til det offentlige

- Indtil 15 dage efter du har indsendt budgetskemaet

- Indtil gælden er betalt tilbage

- Indtil SKAT har behandlet dit budgetskema

- Ved ikke/andet (skriv gerne hvad) 


\section{F6: Hvad kan der ske hvis du sender et budgetskema til SKAT?}

(Sat kun 1 kryds)

- Du kan komme til at betale mere, mindre eller det samme hver måned

- Du kan kun komme til at betale mindre eller det samme hver måned

- Du kan kun komme til at betale mere eller det samme hver måned

- Du kan kun komme til at betale mindre hver måned

- Ved ikke/andet (skriv gerne hvad)

\section{F7: I hvilken situation skal du indsende et budgetskema?} (Sat kun 1 kryds)

- Altid. SKAT har brug for oplysningerne for at finde ud af hvor meget du skal betale

- Hvis du vil være sikker på at skulle betale mindre end der står i brevet

- Hvis du mener du ikke kan betale det beløb SKAT har beregnet at du skal $\underline{\text { betale }}$

- Hvis du vil have slettet din gæld til SKAT

- Ved ikke/andet (skriv gerne hvad)

F8: Hvor på internettet kan du ifølge brevet læse de regler der ligger til grund for afgørelsen?

Skriv svaret her: 


\section{BILAG 5: KATEGORISERING AF SVARENE PÅ DE ÅBNE SPØRGSMÅL (F2, F3 OG F8) SOM ENTEN RIGTIGE EL- LER FORKERTE}

Svarene på F2 (“Hvor meget skylder du ifølge brevet SKAT?”) blev kategoriseret som rigtige eller forkerte efter følgende retningslinjer: Det rigtige svar er 6.675. Hvis beløbet $6.675 \mathrm{blev}$ nævnt som et muligt svar sammen med andre mulige (og ukorrekte) svar, blev det kategoriseret som forkert fordi det viser at respondenten ikke havde været sikker på hvad der var korrekt. Den samlede gæld er ikke regnet sammen i V1. Ved V1 blev svaret kategoriseret som rigtigt hvis respondenten havde skrevet de to beløb der tilsammen udgør den samlede gæld, og knyttet dem sammen med et plustegn. På den måde er det nemlig markeret tydeligt at respondenten var klar over at gælden udgør summen af de to beløb. Hvis der ikke var et plustegn mellem de to beløb, blev svaret regnet som forkert fordi det så var uklart hvilken relation respondenten mente der var mellem de to beløb.

Svarene på F3 ("Hvor stammer din gæld fra ifølge brevet?") blev kategoriseret som rigtige eller forkerte efter følgende retningslinjer: Svaret er regnet som rigtigt hvis respondenten både har skrevet parkeringsafgift og restskat - og evt. tilføjet de forskellige gebyrer som fremgår af den mere detaljerede gældsoversigt man får i V2 (nemlig rykkergebyr og oprettelsesgebyr). Der er ikke skelnet mellem om respondenterne har skrevet parkeringsafgift (i overensstemmelse med brevets ordlyd) eller det i daglig tale mere almindelige parkeringsbode. Forkerte svar omfatter besvarelser hvor der kun står skat eller restgald uden at det er specificeret hvilken type skat eller restgæld der er tale om. Desuden er svar hvor der opgives flere gældsposter end dem der er ifølge brevet, kategoriseret som forkerte.

Formålet med F8 ("Hvor på internettet kan du ifølge brevet læse de regler der ligger til grund for afgørelsen?”) var at finde ud af om respondenterne kunne identificere begge de relevante hjemmesider der blev nævnt i brevet. Et svar blev derfor regnet som rigtigt hvis det omfattede de to hjemmesider der blev nævnt i brevet, nemlig skat. dk og retsinfo.dk. 